\title{
INSTITUCIJE NEPOSREDNE DEMOKRACIJE U MREŽI POLITIČKOG, PRAVNOG I POPULISTIČKOG KONSTITUCIONALIZMA
}

U tekstu se govori o mjestu, ulozi i odnosu predstavničkog sustava i neposredne demokracije unutar trijade političkog, legalnog i popularnog konstitucionalizma. Upućuje se i na ustavnoteorijsku i političku apologiju ustava i ustavnosti, posebno na ulogu ustavnog sudstva u kontekstu razloga i granica korištenja institucija neposredne demokracije unutar ustavnodemokratske organizacije vlasti suvremene države. Posebno se izlažu razlozi o tome zašto - prema autoru - ustavnodemokratsko shvaćanje teksta Ustava Republike Hrvatske ne registrira niske frekvencije sirenskog zova recentnih referendumskih inicijativa, (konkretno onih koje ciljaju na promjenu čl. 72. Ustava, a tiče se broja zastupnika u Hrvatskom saboru, i dopunu Ustava čl. 72.a o uskrati prava glasovanja zastupnicima iz redova nacionalnih manjina o povjerenju vladi i proračunu). Zaključak je autora da je riječ o pokušajima konstitucionalizacije redukcionističkih antiegalitarnih ideja aktualnog populističkog Sturm und Dranga. U tom i sličnom kontekstu Ustavni sud dobiva imperativnu zadaću obrane ustavnih vrednota od ekscesivnog aktivizma kako različitih demagoško-konzervativnih grupa tako i birokratiziranih a indiferentnih stranačkih formacija hrvatske predstavničke demokracije.

Ključne riječi: predstavnički sustav; neposredna demokracija; referendum; populizam; Ustavni sud.

The referendum is an emphatic assertion of the principle that nation stands above parties.

A. V. Dicey ${ }^{1}$

A. V. Dicey to J. Loe Strachey 6 May 1995, Quoted in Richard A. Cosgrove (1981), Albert Venn Dicey: Victorian Jurist, London, Macmillan, p. 107., cit. pr. 12. 
1. Uvodna napomena. Krajem 2005. godine francuski ministar pravosuđa Pascal Clément branio je u parlamentu zakon kojim se retroaktivno predviđala upotreba elektroničke narukvice za praćenje osuđenih osoba. Iako je bio svjestan „ustavnog rizika" retroaktivnosti, aktualni događaji tjerali su ga na prihvaćanje toga rizika, pa je pozivao zastupnike da glasuju za vladin prijedlog ignorirajući pritom odluku Ustavnog vijeća (Conseil Constitutionnela) o neustavnosti takvog poteza. Odgovor Pierrea Mazeauda, predsjednika Ustavnog vijeća, bio je kratak i odrješit: „Poštivanje Ustava nije rizik već dužnost.“2 U tom kratkom iskazu francuskog ustavnog pravnika sažeta je stara i trajna poruka političarima koja, unatoč višestoljetnom iskustvu zloupotrebe vlasti i nužnih promjena političkog sustava, još uvijek snažno govori o važnosti ustava, ustavnom autoritetu i autoritetu konstitucionalizma i njegovoj obrani za njegovu opstojnost i napredovanje. ${ }^{3}$

Do demokratskih političkih revolucija XVIII. stoljeća ustavna ograničenja vlasti odnosila su se na institucije koje se nisu temeljile na općem biračkom pravu. Riječ je o institucijama nasljednog karaktera (monarh) ili onima koje su se temeljile na ograničenom pravu glasa (sastav parlamenta). I tada se ustav razumio kao garancija koja štiti narod od potencijalne tiranije vlasti koju nisu kontrolirali. No, danas, u situaciji općeprihvaćenog prava glasa, ustavna ograničenja odnose se i na institucije koje se temelje na biračkom pravu naroda. Zato ako se na ustav još uvijek gleda iz perspektive "nepovjerenja“ Johna Harta Elya (1938. - 2003.), pisca jednog od najvažnijih djela američke ustavne teorije i prava Democracy and Distrust: A Theory of Judicial Review (1982.), onda je danas predmet nepovjerenja postalo opće biračko pravo i institucije koje iz njega proizlaze. ${ }^{4}$ Zaključak koji se izvodi iz tog rezona govori da je - „ustav

2 Usp. Dominique Rousseau, Constitutionnalisme et démocratie, Texte paru dans laviedesidees.fr, le 19 septembre 2008., p. 2. Engl. verzija teksta: D. Rousseau, Constitutionalism and Democracy, Books and Ideas, 11 May 2015. ISSN: 2105-3030. URL: http://www.booksandideas.net/Constitutionalism-andDemocracy. html.

3 Koristimo se frazom M. P. Madura o tome je li konstitucionalizam kao oblik organizacije vlasti pogodan za EU i, drugo, ima li EU ustavni autoritet (pouvoir constituant) da prihvati takvu organizaciju vlasti. Usp. Miguel Poiares Maduro, The importance of being called a constitution: Constitutional authority and the authority of constitutionalism, International Journal of Constitutional Law, Volume 3, Issue 2-3, 1 May 2005, Pages 332-356, https://doi.org/10.1093/icon/moi023.

4 Teza J. H. Elya u Democracy and Distrust temelji se na stajalištu da bi se Sud trebao posvetiti osiguravanju većinske vladavine uz zaštitu manjinskih prava. Pisac tvrdi da je Ustav nastao iz razumljive pretpostavke da većina neće ugrožavati svoja prava i da ona pritom neće sustavno tretirati druge manje dobro no što tretira sebe. Ustav to omogućuje, prvo, strukturirajući procese odlučivanja na svim razinama tako da u donošenju odluke jamči predstavništvo svih interesa. I drugo, da primjena takvih odluka neće biti manipulirana na način da u praksu ponovno uvede onaj oblik diskriminacije koji je teorijski nedopustiv. O ovom važnom djelu američke ustavnopravne teorije v. Paul N. Cox, John Hart Ely, Democracy and Distrust: A Theory of Judicial Review, 15 Val. U. L. Rev. 637 (1981). Available at: http:// scholar.valpo.edu/vulr/vol15/iss3/6Dorf, Michael C., Putting the Democracy in Democracy and Distrust: 
garancija protiv naroda: ustav štiti ustavna prava narodne volje ili njihovih izabranih predstavnika“. ${ }^{5}$ Dok je izvorna ideja ustav sagledavala kao političko sredstvo diobe vlasti kako bi se nadziralo i ograničavalo obnašanje vlasti bez izbornog legitimiteta, danas je ustav legalno sredstvo zaštite temeljnih prava protiv obnašanja vlasti koja ima izborni legitimitet. Upravo je zbog toga Vrhovni sud SAD-a za predsjednikovanja Earla Warrena (1953. - 1969.) za Elya djelovao „legitimno i herojski“ jer je svojim odlukama štitio individualna prava koja su se dotada sustavno zanemarivala u političkom procesu. ${ }^{6}$

Tako navedena radikalna promjena perspektive traži ponovno otvaranje pitanje o značenju konstitucionalizma s obzirom na to da značenje fraze "demokracija prema ustavu" (ustavna demokracija) ovisi o tome imaju li vlasti o kojima ustav govori ili nemaju izborno podrijetlo. A u ovom kontekstu onda ustav kao najviša garancija temeljnih prava proizvodi demokraciju koja svojim novim karakteristikama na poseban način ističe mjesto i ulogu ustavnih sudaca i kontrole ustavnosti zakona. U shvaćanju novije ustavnodemokratske teorije:

... ustavna revizija vraća narod nazad u postojanje kao autonomnu i suverenu osobu (...) reprezentacija je scena na kojoj dva aktera igraju različitu ulogu: izabrani predstavnici su delegati suverena, a narod je suveren. ${ }^{7}$

Ukratko ćemo rasvijetliti mjesto, ulogu i odnos predstavničkog sustava i neposredne demokracije unutar trijade političkog, legalnog i popularnog konstitucionalizma ${ }^{8}$. Ukazujemo i na ustavnoteorijsku i političku apologiju ustava

The Coherentist Case for Representation Reinforcement (2004). Cornell Law Faculty Working Papers. Paper 73. http://scholarship. law.cornell.edu/clsops_papers/73; John Hart Ely, Democracy and Distrust: A Theory of Judicial Review, Harvard University Press, 1981., p. 280; Richard A. Posner, Democracy and Distrust Revisited, 77 Virginia Law Review 641 (1991); Kaufman, Andrew L. (1981), Democracy and Distrust. By John Hart Ely, Hofstra Law Review: Vol. 9: Iss. 3, Article 6; Reviewed Work: Democracy and Distrust: A Theory of Judicial Review by John Hart Ely Review by: Richard W. Burgh, Law and Philosophy, Vol. 1, No. 3, Values in the Law of Tort: Part I (Dec., 1982), pp. 481-487; Rosalind Dixon, Constitutional drafting and distrust, International Journal of Constitutional Law, Volume 13, Issue 4, 1 October 2015, Pages 819-846, https://doi. org/10. 1093/icon/mov068.

5 Usp. D. Rousseau, Constitutionnalisme et démocratie, Texte paru dans laviedesidees.fr, le 19 septembre $2008 .$, p. 4.

6 Neal Devins, The D'Oh of Popular Constitutionalism, Michigan Law Review, Vol. 105, April 2007, p. 1333

$7 \quad$ D. Rousseau, op. cit., p. 6.

8 „Direktna demokracija (DD) dopušta građanima da preko institucija referenduma i inicijative izravno utječu na političke odluke. U prvom slučaju pitanje referenduma u rukama je vlade, dok se u drugom slučaju omogućuje građanima da svoju agendu uređuju čak i suprotno očekivanjima vlade. U proteklih pola stoljeća direktnu je demokraciju omogućio veliki broj zemalja novim ustavima ili promjenama starih." Usp. Lorenz Blume, Bernd Hayo and Stefan Voigt, Correlates and Determinants of Direct Democracy, Helen Gregorczuk, Citizen Initiated Referendums - Republican Innovation or Scourge of Representative Democracy, 7 Griffith L. Rev. 249 (1998); Derrick A. Jr. Bell, The Referendum: Democracy's Barrier to Racial Equality, 54 Wash. L. Rev. 1 (1978). 
i ustavnosti, posebno na ulogu ustavnog sudstva u kontekstu razloga i granica korištenja institucija neposredne demokracije unutar ustavnodemokratske organizacije vlasti suvremene države. Napokon, namjeravamo posebno istaknuti razloge zašto - prema našem mišljenju - ustavnodemokratsko shvaćanje teksta Ustava Republike Hrvatske ne registrira niske frekvencije sirenskog zova recentnih inicijativa, konkretno onih koje ciljaju na promjenu čl. 72. Ustava (broj zastupnika u Hrvatskom saboru) ${ }^{9}$ i dopunu čl. 72.a Ustava (o uskrati prava glasovanja zastupnicima iz redova nacionalnih manjina o povjerenju vladi i proračunu $)^{10} \mathrm{kao}$ pokušajima konstitucionalizacije novih redukcionističkih antiegalitarnih ideja aktualnog populističkog Sturm und Dranga. U tom i sličnom kontekstu Ustavni sud dobiva imperativnu zadaću obrane ustavnih vrednota od ekscesivnog aktivizma kako različitih demagoško-konzervativnih grupa tako i birokratiziranih a indiferentnih stranačkih formacija hrvatske predstauničke demokracije.

\section{Ustavna demokracija i predstavnički sustav. Za Johna Stuarta Milla} (1806. - 1873.) reprezentativna demokracija jednostavno je značila mogućnost da: ,,... narod ili njegova većina, preko svojih predstavnika biranih s vremena na vrijeme obnaša ultimativnu kontrolu vlasti, koja, prema svakom ustavu, negdje mora počivati“. ${ }^{\prime 1}$ To znači da se predstavnička demokracija kao oblik posredne (indirektne) vladavine nužne za vladavinu nad većim brojem ljudi temelji na transferu autoriteta od naroda na njegove predstavnike. S druge strane, pojam neposredne (direktne) demokracije upućuje na vladavinu naroda, odnosno na njegovu samoupravu. Budući da je to moguće jedino na malom teritoriju s malo stanovnika, najveći je broj država, radi efikasnosti, prihvatio predstavnički sustav. No, da bi sustav bio demokratski, on mora u sebi sadržavati principe političke jednakosti i dogovorne vlade. ${ }^{12}$ Birači moraju računati na jednaku reprezentaciju u predstavničkom tijelu, a predstavnici moraju biti odgovorni biračima kroz redovne povremene izbore.

Teorija predstavničke demokracije konzistentna je prema odredbama parlamentarne vlade koja počiva na uvjerenju da je parlament najviša skupština predstavnika iz svih krajeva jedne zemlje ili države koji će slobodno raspravljati i odlučivati o temeljnim pitanjima javne politike. Predstavnici koje je izabrao narod moraju biti slobodni: oni djeluju po osobnoj savjesti i slobodni su od svake veza-

9 Ustav Republike Hrvatske: Članak 72.: „Hrvatski sabor ima najmanje 100, a najviše 160 zastupnika koji se, na temelju općeg i jednakoga biračkog prava, biraju neposredno tajnim glasovanjem."

Otkriveno kako će glasiti referendumska pitanja inicijative 'Narod odlučuje', https://www.tportal.hr/vijesti/ clanak/ otkriveno-kako-ce-glasiti-referendumska-pitanja-inicijative-narod-odlucuje-20180428.

11 John Stuart Mill, Considerations on Representative Government, first published 1861, new edition, R.B. McCallum, ed., Basil Blackwell, Oxford, 1946.

12 Usp. A. H. Birch, Representation, Macmillan, London, 1972, p. 35; Joseph Raz, Government by Consent, Nomos, Vol. 29, Authority Revisited, 1987., pp. 76-95. 
nosti za interese svog biračkog tijela ili neke druge grupne interese. Predstavnici u parlamentarnom sustavu izabrani su zbog svojih zasluga te moraju djelovati $u$ skladu sa svojim uvjerenjima u nacionalnom interesu; oni moraju biti vođe i edukatori, a ne samo delegati vezani partikularnim interesima. Dalje, predstavnici za razliku od prosječnog građanina - imaju ili će steći umijeća i znanja koja će im omogućiti svladavanje kompleksnog političkog odlučivanja. Predstavnici su kvalificiraniji za donošenje takvih odluka jer su plaćeni kako bi posvetili svoje vrijeme funkcijama vlasti, a ne zato što su moguće bistriji ili javno svjesniji od drugih.

Glavna uloga građana u predstavničkoj demokraciji koja se temelji na sustavu parlamentarne vlade jest legitimizacija sustava izborom parlamentarnih zastupnika. Narod ima pravo birati svoje zastupnike; ako ti zastupnici ne izvršavaju svoju funkciju na zadovoljavajući način, narod ih na idućim izborima može smijeniti. U tom je smislu najvažnija tema predstavničke demokracije više nego očita: vlast na ultimativan način počiva u narodu; ipak - uzima se - ako narod i nije fizički nazočan u tijelu vlasti, blizu joj je.

Za razliku od neposredne demokracije, $\mathrm{u}$ kojoj vlada jednakost između upravljača i upravljanih, predstavnički režim vladavina je naroda preko narodnih izabranika, odnosno preko narodnih predstavnika ili zastupnika. Vlast građana rezimira se i iscrpljuje izborom predstavnika. Građani moraju imati povjerenje $u$ kompetentne pojedince. Pojam reprezentant (predstavnik) bio je rezerviran za one koji su djelovali uime naroda. Tijekom vremena identitet predstavnika izjednačio se s članom parlamenta (zastupnikom) ${ }^{13}$. Predstavnici naroda između dva izbora, dvije izborne konzultacije, imaju niz mogućnosti. Njihov mandat nije samo neograničen nego je i neopoziv, što je suprotno viziji koju imaju pravnicicivilisti. Narod ne može ništa učiniti protiv zakona usvojenog na temelju ustava. Od protivljenja i rasprava nakon donošenja zakona nema nikakve koristi. Dakle, postoji juridička fikcija o presumpciji neoborive suglasnosti između predstavnika i onih koje oni predstavljaju. Potonja je konstrukcija imala teške posljedice na participaciju i alijenaciju građana, demokraciju i oligarhiju, ukratko za sporove narodnog i parlamentarnog suvereniteta.

Klasični je liberalizam postuliranjem posredničke uloge predstavničkog sustava na određeni način prisvojio demokratsku logiku, suveren je podvrgnut dominaciji predstavnika. J. J. Rousseau imao je pravo kada je govorio o moguć-

Treba podsjetiti da je u suvremenoj državi popularnu investituru počela koristiti i egzekutiva. Napoleon je još 1814. godine izvikivao: „Francuska nema drugog predstavnika osim mene.“ Slično je izjavljivao 1964. godine i De Gaulle: „Narod koji je izabrao predsjednika, predao mu je u potpunosti nedjeljivi državni autoritet." Usp. C. De Gaulle, Discours et Messages, IV, Paris, Plon 1970, p. 168. ; Véronique Dimier, For a Republic 'Diverse and Indivisible'? France's Experience from the Colonial Past, Contemporary European History, Vol. 13, No. 1 (Feb., 2004), pp. 45-66. 
nosti „uzurpacije“ vlasti. No, razvojem klasičnog ustavnog prava osmišljena su rješenja kojima su se pogreške nastojale ispraviti. ${ }^{14}$

\section{O prevladavanju predstavničkog sustava - A. v. Dicey i pitanje referen-} duma u „engleskom ustavu“. Na Zapadu je više država nastojalo obnoviti prerogative demokracije što ih je tijekom vremena uklonio predstavnički sustav. Taj je pokret imao sociološki i juridički aspekt, a rezultirao je novom podjelom vlasti između građana i njihovih predstavnika. Naknadna afirmacija narodne inicijative, referenduma, popularnog veta, opoziva (federalni recall u SAD-u, Abberufungsrecht u Švicarskoj) itd. neoborivi su dokazi o korekcijama izvornog predstavničkog sustava. Najsnažnija korekcija francuske tzv. Republike zastupnika (La république des députés) ${ }^{15}$ jest poluneposredna demokracija (democratie semi-directe), kao svojevrsni ",treći“ modalitet obnašanja suvereniteta, sretnija sinteza između idealne, ali neostvarive ideje neposredne (direktne) demokracije, s jedne strane, te predstavničkog sustava, s druge, koji se mutatis mutandis primjenjuje u više oblika. Stoga se s pravom govori o klasifikaciji ili tipologiji različitih političkih režima, organiziranoj prema kriteriju distribucije ili centralizacije suvereniteta. ${ }^{16}$

Među najuglednijim tumačima klasičnog predstavničkog sustava bio je i klasik A. V. Dicey (1835. - 1922.), koji je ostavio relevantne ocjene o njegovim prednostima i defektima. ${ }^{17} \mathrm{No}$, neprikosnoveni tvorac doktrine parlamentarnog suvereniteta bio je i jedan od prvih teoretičara "zaokružene“ i „koherentne“ političke teorije o referendumu..$^{18}$ Najznačajnija njegova ideja jest ona o referendumu kao alternativnom drugom domu koju razvija u Uvodu u pravo Ustava i u tekstu pod naslovom Mora li se referendum uvesti u Englesku. ${ }^{19}$ Njegova je ideja bila da, za razliku od Gornjeg doma (House of Lords), referendum predstavlja ,,jedinu moguću kontrolu partijskih vođa" i jedinu instituciju koja je mogla

\footnotetext{
14 Simon Tormey, The Contemporary Crisis of Representative Democracy, https://www.aph.gov.au/About Parliament/ Senate/Powers_practice_n_procedures/pops/ Papers_on_Parliament _66/The_Contemporary_Crisis_of_Representative_Democracy. Roger Priouret, La république des députés, Pariz, 1967., p. 268.

16 Joel Krieger, The Oxford Companion to Comparative Politics, Vol. I-II, OUP USA, 2012., p. 1360.

17 A. V. Dicey, Comparative Constitutionalism, Ed. by J.W.F. Allison, Oxford University Press, Oxford 2013, p. 215-228; Introduction to the study of the Law of the Constitution, London, 1961., 82-85.

18 Matt Qvortrup, A Tale Of Two Referendums - Elite manipulation or Civic Engagement, The Constitution Society, London, 2015., p. 11.

19 O tome M. Qvortrup (1999) A.V. Dicey: The Referendum as the People's Veto, in History of Political Thought,. Vol.20, No.3, pp. 531-546.
} 
... dati formalno priznanje doktrini koja je ležala u temeljima engleske demokracije naime da donošenje zakona zavisi od suglasnosti nacije koju predstavljaju njeni elektori. ${ }^{20}$

Ozbiljno zabrinut zbog nezadrživih i moguće revolucionarnih promjena „engleskog“ ustava, A. V. Dicey zagovarao je primjenu referenduma za sve važne promjene. On je cijenio referendum prije svega zbog toga što referendum odbacuje - striktno govoreći - postojeći apsurdni sustav koji djeluje na pretpostavci da birači mogu dati najbolji odgovor na postavljeno pitanje, npr. ono o Home Rule, pa makar ga stavili zajedno uz neka sasvim različita pitanja poput onog o prohibiciji... i, drugo, možda uglavnom iz razloga što referendum snažno naglašava princip prema kojemu nacija stoji iznad stranaka. Unatoč svemu referendumi u Engleskoj počeli su se primjenjivati tek u drugoj polovici 20. stoljeća. ${ }^{21}$ Danas referendum predstavlja živu temu tekuće rasprave o odnosu političkog i pravnog konstitucionalizma.

\section{Institucije neposredne demokracije u fokusu političkog i pravnog kon-} stitucionalizma. Tema implementacije institucija neposredne demokracije kao dio rasprave o nedostatcima reprezentativne demokracije raspravlja se danas i unutar odnosa političkog i pravnog konstitucionalizma. Diskurs je svoje najviše domete ostvario u Ujedinjenom Kraljevstvu, ali kako je riječ općenito o manjkavostima suvremenog konstitucionalizma i načinima kako ga vratiti u život, diskusija se razbuktala i drugdje. Ta opća rasprava zapravo je ponovno pokazala da politički i legalni konstitucionalizam treba promatrati kao modele strukturiranja i ograničavanja državne vlasti.

Ujedinjeno Kraljevstvo ima u tradicionalnom smislu politički ustav, što nije ništa drugo nego koncept povezan s parlamentarnim suverenitetom, fuzijom vlasti, majoritarnim pojmovima demokracije te političkim metodama odgovornosti. U ovom modelu organizacije vlasti legislatura se teoretski sagledava kao nositelj najveće moguće vlasti i legitimiteta. To je zbog toga što se parlament kao izabrano tijelo sagledava kao predstavnik interesa većine, pa mu je povjerena vlast za koju je politički odgovoran. Ipak, engleski konstitucionalizam u praksi izgleda ponešto drugačije zato što značajne ovlasti ima vlada. $U$ tome modelu legislatura i egzekutiva međusobno su isprepletene; ministri naime dolaze iz Donjeg i Gornjeg doma, tako da se teško ostvaruju efikasne legalne kontrole i provjere. Nema jasne podjele vlasti u smislu tradicionalnog koncepta koji je važan čuvar protiv zloupotrebe vlasti i odgovornog

\footnotetext{
20 A.V. Dicey (1911) A Leap in the Dark, London, John Murray, 2nd Edition, pp. 189-190. Cit. pr. M. Qvortrup, A Tale Of Two Referendums - Elite manipulation or Civic Engagement, The Constitution Society, London, 2015., p. 12.

21 A. V. Dicey to J. Loe Strachey 6 May 1995, Quoted in Richard A. Cosgrove (1981) Albert Venn Dicey: Victorian Jurist, London, Macmillan, p. 107.
} 
načina vladanja zemljom. Temelji političkog konstitucionalizma u Ujedinjenom Kraljevstvu počivaju dakle pretežno na parlamentarnom suverenitetu, koji pojam nastaje $\mathrm{u}$ povijesnom procesu odbijanja snažnih i svugdje prisutnih monarha za vrijeme trajanja engleske revolucije, koja je rezultirala Slavnom revolucijom iz 1689. Iako je pod Charlesom II. monarhija bila restaurirana, između krune i parlamenta nastali su i razvijali su se novi odnosi.

Pravni konstitucionalizam, za razliku od političkog konstitucionalizma, teorijski je utemeljen na vladavini prava. Ovdje je jači naglasak na podjeli vlasti i snažnija želja da se nad upravljačima primjenjuje sustav pravnih kontrola i provjera. Unutar tog modela separatno i nepristrano sudstvo pomaže kontroli i ograničavanju izvršne vlasti. Riječ je o načinu vladavine kojem UK i dalje mora težiti u nastojanju da se zaštite temeljna prava i garancije protiv tiranije. Zbog njene duge prisutnosti i ukorijenjenosti, bilo bi teško mijenjati ili reformirati podjelu vlasti između egzekutive i legislature, što se danas sve više odnosi i na odvojenost sudbene vlasti. Tako se konzekventnim slabljenjem tradicionalnog westminsterskog modela i fragmentiranjem povijesnog i političkog Ustava suvremena Britanija pomaknula prema više legalnom ustavu, što je najuočljivije u novim i izmijenjenim ovlastima sudstva ostvarenim tijekom procesa usvajanja Human Rights Acta (1998.) i uspostave Vrhovnog suda (2009.). ${ }^{22}$

Odnos političkog i legalnog konstitucionalizma aktualizirao je, naravno, i referendumski Brexit kao "fini primjer vladavine prava i britanskog ustava u akciji“. No i ovdje je došla do izražaja uloga neovisnih sudaca koji su - razmatrajući pitanja građanske inicijative - posljednji odlučivali o zakonitosti jedne ministarske odluke. ${ }^{23}$ Ali došla je do izražaja i uloga parlamenta i njegova odgovornost za referendumsku legislativu i niz pitanja o razdoblju održavanja referenduma, datumu te pitanjima o kojima se odlučuje. Vlada je - naglašavajući pravo parlamenta da odlučuje o posebnim prilikama za svaki posebni referendum te o

$\overline{22}$ Prijelaz s političkog na pravni ustav demonstriraju sljedeća dva slučaja. Prvi je slučaj zapravo maskirana politička odluka i sudovima koji su imali manje moći da podrže prava. Tzv. Wednesbury test imao je vrlo visoki prag: ,,... odluka o kompetentnoj stvari je toliko nerazumna da je ne bi dokučio niko razuman u vlasti, stoga se sudovi mogu umješati. Odluka je bila kritizirana kao preopćenita i loše definirana. Takav test je karakterističan za politički ustav budući tamo postoji i zahtjev za sudskim samoograničenjem kako se ne bi zakoračilo u suštinsko odlučivanje. Za razliku od prvog drugi slučaj dozvoljava sudu legitimnu fleksibilnost u rezoniranju. U ovoj je fazi common law omogućio korektan ishod dok je ECHR podrška omogućujući sudu povjerenje u obrani prava. Tako je Human Rights Act dopustio sudovima još bliži uvid u odluku donijetu unutar zahtjeva za sudskom revizijom, čime se je stvarala mogućnost još intenzivnijeg procesa revizija." Usp. Sarah Pearson, Political Constitutionalism and Legal Constitutionalism: Where Does the Judiciary Lie at the Heart of This Tension, 3 Southampton S. L. Rev. 29 (2013).

Supreme Court president: Court won't overturn Brexit vote, https://www.bbc.com/news/uk-politics-38247937; Referendums in the United Kingdom,-- Report with Evidence, HL Paper, House of Lords, Select Committee on the Constitution, 12th Report of Session 2009-10. 
tome hoće li se uopće i kada referendum održati - takvim stajalištima snažno podupirala temeljne principe predstavničke demokracije.

Evidentna proliferacija referenduma u Ujedinjenom Kraljevstvu i drugdje nakon 1989. godine empirijski potvrđuje sve aktivnije izravno sudjelovanje naroda u općim ustavnim procesima. Međutim, taj proces otkriva međusobno uvjetovano stanje u kojemu politički konstitucionalisti osuđuju liberalni legalizam zbog nedostatka demokratskog legitimiteta, ali zatvaraju oči pred činjenicom da upravo kritičan rast oblika izravne demokracije ugrožava demokratski legitimitet reprezentativnog modela. ${ }^{24}$

5. Referendum u percepciji populističkog konstitucionalizma. Suvremenu ustavnopravnu raspravu u najnovije vrijeme obogatio je još jedan oblik konstitucionalizma koji prije svega karakterizira populizam. Većina teorijskih izvora populizam definira kao - ,grupu ideja koja se temelji ne samo na moralnoj i manihejskoj razlici između 'čistog naroda' i 'korumpirane elite' već i na koncepciji politike kao afirmaciji navodne volje naroda ${ }^{\prime 25}$. Populistički konstitucionalizam ilustrira uspon nacionalističkih stranaka u Mađarskoj i Poljskoj, koje se otvoreno protive projektu Europske unije, uspjeh antieuropske većine u Ujedinjenom Kraljevstvu, koje je izglasalo Brexit, prodor populističkih lidera u nizu zemalja Latinske Amerike te napokon, izbor notornog političkog diletanta za predsjednika SAD-a (2016.). Imajući u vidu nužnost sudjelovanja naroda u demokratskoj ustavnoj politici, praksa je omogućila razlikovanje poželjnih i manje poželjnih oblika participacije naroda u procesu ustavne implementacije. U jednom slučaju govori se o oblicima popularnog, a u drugom o oblicima populističkog konstitucionalizma. Dok popularni konstitucionalizam pridonosi demokratskoj legitimaciji ustavnog sustava, pojedini kriteriji koji omogućuju efektivno razlikovanje jednog oblika konstitucionalizma od drugog ne osiguravaju pozitivnu reputaciju populističkom konstitucionalizmu. ${ }^{26}$

Jan-Werner Müller sugerira da se populistički konstitucionalizam sastoji od tri ključna elementa: (i) njegovi zagovornici tvrde da oni predstavljaju ili govore

24 Stephen Tierney, Whose Political Constitution? Citizens and Referendums, German Law Journal, Vol. 14., No. 12, p. 2190.

Cristóbal Rovira Kaltwasser, Populism vs. Constitutionalism? Comparative Perspectives on Contemporary Western Europe, Latin America, and the United States, The Foundation for Law, Justice and Society, in association with the Centre for Socio-Legal Studies andWolfson College, University of Oxford, 2013, p. 3.

Cesare Pinelli,The Populist Challengeto Constitutional Democracy, European Constitutional Law Review, 7: 5-16, 2011; Cristóbal Rovira Kaltwasser, Populism vs.Constitutionalism? Comparative Perspectives on Contemporary Western Europe, Latin America, and the United States, The Foundation for Law, Justice and The Foundation for Law, Justice and Society in association with the Centre for Socio-Legal Studies andWolfson College, University of Oxford, Oxford, 2013.; William Partlett, The Dangers of Popular Constitution-making, Brook J. Int' L.L. . [Vol. 38:1, 2012]. 
uime volje, pogleda ordinarnih ljudi i u toj vezi nema mjesta za posredovanje tradicionalnih demokratskih institucija (političke stranke, parlamentarne ili sudbene strukture); (ii) na djelu je diskurs koji je kritičan prema postojećim političkim i institucionalnim rješenjima; (iii) zagovara se politika koja je inherentno isključiva i antipluralistička. Upravo potonja karakteristika predstavlja "ključ“ razlikovanja između populističkih i popularnih oblika konstitucionalizma. ${ }^{27}$

Paul Blokker pak uz populistički konstitucionalizam povezuje četiri ključne dimenzije: narodnu volju, majoritarizam, legalni resantiman i ustavni instrumentalizam. Narodnu volju populisti razumiju na zatvoreni, jedinstveni način i kao negaciju pluralističke i diarhične prirode reprezentativne demokracije. Većinu (majoritarizam) populisti razumiju prije kao kolektivni unitarni entitet negoli kao agregat, što je slučaj u liberalizmu, a isti ide zajedno s odbacivanjem političkih manjina i opozicije. Legalni resantiman odnosi se na kritiku tendencije formalne racionalizacije, juridifikacije i egzaltacije političkog $\mathrm{u}$ (liberalnom) konstitucionalizmu. Ustavni instrumentalizam odnosi se na kombinaciju konstitutivnog i konstituirajućeg, tako da se ustav ne razumije kao više pravo već kao temeljni zakon koji se ima mijenjati prema političkoj nužnosti. Naposljetku, suma tih stajališta jest $u$ tome što on dokazuje da se izazov populističkog konstitucionalizma za liberalni konstitucionalizam i predstavničku demokraciju nalazi u vezi s revolucionarnom ustavnom tradicijom, ali interpretiranom i iskrivljenom na problematičan način, što najbolje izražava poseban populistički pristup narodnoj volji, majoritarizmu, vladavini prava i konstitucionalizmu. ${ }^{28}$

Na ovome mjestu treba posebno skrenuti pozornost na dva elementa: majoritarizam i ustavni instrumentalizam. Populistički ustavni projekt u suštini predstavlja pokušaj 'ispravljanja', štoviše potkopavanja predstavničke demokracije i ideje socijalnog i političkog pluralizma. Populisti su inspirirani mitom o unitarnom Narodu, oni su protiv fragmentacije, konfliktnih podjela te „izvještačenosti“ predstavničke demokracije. Populisti osporavaju metodu predstavničke demokracije koja ideju narodnog predstavništva koju verificira narod daje prije svega sredstvima izbornih procedura. Populisti smatraju da agregacija koja se pojavljuje u demokratskim izborima reprezentativne demokracije nije uopće Narod nego kalkulirana suma

27 Usp. Jan-Werner Müller, Populist Constitutionalism: A Contradiction in Terms?; http://www.law.nyu.edu/ sites/default /files/upload_documents/JWMuellerNYULaw-PopulistConstitutionalism.pdf; Jan-Werner Müller, The People Must be Extracted from Within the People: 'Reflections on Populism', in: Constellations, vol. 21 (2014), 483-93;'Towards a Political Theory of Populism', in: Notizie di Politeia, no. 107 (2012); Jan-Werner Müller, Što je populizam, Zagreb 2017, str. 134; Dixon, Rosalind: Populist Constitutionalism and the Democratic Minimum Core, VerfBlog, 2017/4/26, https:// verfassungs blog. de/populist-constitutionalism-and-the-democratic-minimum-core/, DOI: https://dx.doi.org/10.17176/ 20170426-093914. Routledge; David Landau, Populist Constitutions, The University of Chicago Law Review, 2018, 85: 521. 
pojedinaca bez oblika suštinskog zajedništva i kolektivne posvećenosti. Oni polaze od toga da grupama iza scene koje operiraju zbog razloga vlastitog interesa a ne općeg dobra i običnih građana. Politički cilj populista jest većina koja se ne razumije više kao agregat različitih grupa i interesa koja izražava privremenu podršku vladi, već

stvarna i trajna većina - empirijski provjerljiva - koja daje izraz općoj volji Naroda. Tad je većina egzaktno onaj dio društva koji je u dosluhu s populističkim političkim programom kojeg može otjelotvoriti lider koji izražava narodni glas (...) Populisti promoviraju ustavne, izborne i neposredno- demokratske instrumente koji podupiru većinsku ili plebiscitarni vladavinu, i to često na štetu političke opozicije. ${ }^{29}$

Populistički projekti naglašavaju dakle majoritarne aspekte demokracije ne prihvaćajući liberalne kontrole vlasti većine. Korištenjem izbornog inženjeringa, institucija poput izbornih komisija, sudova i medija, ocrtava se polje političke igre na kojemu je posijan niz zamki kojima je cilj onemogućiti opoziciji povratak na vlast. Populistima nije dovoljno osvojiti većinu i osloboditi je stega već i ojačati u uvjerenju da su njihovi politički oponenti ilegitimni i da ne zaslužuju biti na vlasti. ${ }^{30} \mathrm{U}$ tom smislu liberalizam i demokracija erodiraju istodobno. ${ }^{31}$

U populističkoj ofanzivi koju komparativisti nazivaju okupacijom države otkriva se specifični, instrumentalistički pristup donošenju i promjeni ustava. U populističkom konstitucionalizmu to je ponašanje rezultat negativne evaluacije liberalnog konstitucionalizma (legalni resantiman) koji sebe manifestira u shvaćanju ustavnog statusa kao rigidnog višeg prava, na čemu inače inzistira liberalni ili legalni konstitucionalizam. $U$ tom smislu instrumentalni pristup ogleda se $\mathrm{u}$ čestim ustavnim promjenama, što je rezultat stava da ustav treba biti otvoren izmjenama i dopunama već prema potrebama političke većine i/ili nužnostima posebnih povijesnih prilika. Najrječitiji su primjeri mađarskog Temeljnog zakona koji se nakon usvajanja 2012. mijenjao šest puta te napadi poljske Vlade na Ustavni i Vrhovni sud. Suština toga stava jest $\mathrm{u}$ tome što se „statična temporalnost legalnog konstitucionalizma odbacuje u korist izravnijeg političkog odnosa sa konstitucionalizmom ${ }^{\prime \prime 32}$. A u njemu se onda konsekventno objavljuje fundamentalni populistički kanon da je ustav prije zamašnjak narodne volje negoli njeno iole značajno ograničenje. ${ }^{33}$

\footnotetext{
29 Urbinati, N. (1998), 'Democracy and populism,' Constellations, 5(1), 110-124. Cit. pr. Paul Blokker, Populist Constitutionalism, in: Carlos de la Torre (Ed.), Routledge Handbook of Global Populism, Routledge; p. 9.

David Landau, Populist Constitutions, p. 533; Gábor Halmai, An Illiberal Constitutional System in the Middle of Europe.

Paul Blokker, op. cit. p. 10 et passim.

Tully, J. (2008), Public philosophy in a new key, Cambridge University Press. Cit. pr. P. Bokker, op.cit. p. 13
} 
6. Ustav "postreprezentativne demokracije“ $i$ institucije neposredne demokracije. O dugoj evoluciji predstavničkih sustava, posebno parlamentarne demokracije, te njenom usponu i padovima uvjerljivo je govorio još Carl Schmitt (1888. - 1985.), koji je u svom djelu o krizi parlamentarne demokracije (Die geistesgeschichtliche Lage des heutigen Parlamentarismus) iz 1923. godine snažno i uvjerljivo kritizirao „njene nekonzistentnosti“. Tenzije između parlamentarizma i demokracije koje je analizirao Schmitt kao i njegova kritika liberalne demokracije aktualni su i dobivaju na intenzitetu. Evidentna je danas opća kriza predstavničkog sustava, nezadrživa mallaise constitutionnel ili ustavna boljetica, kako ju je pred gotovo stoljeće nazivao Karl Loewenstein..$^{34}$ Dovoljno je danas podsjetiti se atmosfere permanentnog skandala oko administracije $D$. Trumpa koji se reflektira u diletantskoj i nesuvisloj raspravi jednog demagoga s medijima, parlamentarnim odborima te kritičkim javnim mnijenjem. ${ }^{35}$ No, pravi podtekst dinamične $\mathrm{i}$ konfuzne rasprave $\mathrm{u}$ tom kontekstu jest zapravo nepovjerenje dijelova političke elite u demokraciju, posebno ako ona poprima cezarističku dimenziju - tj. kada se ona obraća izravno narodu zaobilazeći inicijative velikih političkih stranaka i ostvarujući se pritom izvan njihovih gabarita.

Danas je više nego evidentna i upozoravajuća globalna rasprava o krizi s kojom se suočava predstavnička demokracija. Govori se o postdemokratskoj eri u kojoj su demokratske institucije samo formalno intaktne; o demokratskom deficitu od kojeg pate suvremena društva, zagovaranju jake demokracije, povratku političkog itd. Iako niz istraživanja pokazuje kako je „povjerenje u politički proces palo do šokirajuće razine ${ }^{\prime \prime 36}$, demokracija kao "politički poredak u kojemu vlada većina“, a posebno ustavna demokracija kao politički poredak u kojemu ustav ograničava i vlast većine, i dalje uživa povjerenje ma koliko ono bilo uzdrmano. Naravno da za pobornike demokracije sve izraženije javno nepovjerenje koje se manifestira kako u smanjenju broja birača koji izlaze na izbore tako i broja članova u političkim strankama nije nevažno. Nezadovoljstvo politikom može građane dovesti u situaciju propitivanja samih temelja demokratskih načela. Američki je politolog David Easton upozoravao na tzv. spillover effect kojim se ugrožava javno prihva-

34 Karl Loewenstein, Reflections on the Value of Constitutions in Our Revolutionary Age, u Constitutions and Constitutional Trends since World War II, An Examination of Significant Aspects of Postwar Public Law with Particular Reference to the New Constitutions of Western Europe, Ed. by A. J. Zurcher, New York University, New York University Press, 1951., http://clclibrary-org.tripod.com/Eeu.html; http://clclibrary-org.tripod.com/Eeu2.html; http://clclibrary-org.tripod.com/Eeu3.html.

W. Davies, Johnson, Trump and the rise of radical incompetence, The New York Times International Edition, July 14-15, 2018, p. 9. No. 04, p. 714. 
ćanje onih odluka koje dolaze u konflikt s osobnim interesima i vrijednostima. Bezbroj je primjera koji pokazuju da demokracija nikada nije učinkovita bez temeljne vjere $\mathrm{u}$ njen legitimitet. ${ }^{37}$

Kako se to stanje može objasniti? Diljem razvijenih ustavnih demokracija politička kultura dugo se temeljila na lojalnim i pomirljivim stajalištima javnosti prema političkom autoritetu, ali u toj su javnosti pojedinci postupno gubili interes utjecanja na politički sustav. A to je bilo zbog toga što je postojeća politička kultura omogućavala proces akomodacije političke elite nadmoći egzekutive $u$ kojoj vlada i političke elite mogu oblikovati politiku i političke mjere bez prevelikog miješanja publike. To je stanje trajalo sve do pojave aktualne „referendumske ere ${ }^{38} \mathrm{Niz}$ je pokazatelja iz nacionalnih istraživanja s kraja 20. stoljeća koja pokazuju kontinuirano snižavanje razine političkog povjerenja naroda prema politici i političarima. Fenomen nepovjerenja i „posvemašnjeg ciničnog ponašanja" koje građani izražavaju prema političkom sustavu i političarima (izborna apstinencija, nezadovoljstvo, nepovjerenje, građanska pasivnost...) povezuje se s pojavom i nadiranjem velikih socijalnih i ekonomskih problema koje velike političke stranke nisu u stanju riješiti. Komparativna istraživanja indiciraju da građani u više zemalja vjeruju kako izabrani političari i dužnosnici ne predstavljaju narod već kombinaciju izbornog tijela, regionalne, nacionalne i partijske interese, a ponekad i interese posebnih interesnih grupa. Orijentacija građana prema korekciji kriznih stanja predstavničkog sustava upotrebom populističkih političkih instrumenata stavlja u pitanje legitimnost svakog političkog sustava u pitanju. Onog trenutka kada politički sustav počinje osjećati krizu legitimnosti pojavljuju se i novi zahtjevi za promjenom, uključujući tu i zahtjeve za promjenom ustavnog dokumenta zemlje. ${ }^{39}$

Stanje na širokoj fronti komparativnog ustavnog prava pokazuje dakle da su se politička ponašanja i pozicije građana u mnogim razvijenim zemljama promijenili. Riječ je o stanju koje može biti

$\overline{37}$ David Easton, A Re-Assessment of the Concept of Political Support, 5 Brit. J. Pol.. Sci. 435, 444 (1975); Carlo Invernizzi Accetti and Alessandro Mulieri, Critical Exchange Debating representative democracy u svom članku u kojem analiziraju knjigu Nadie Urbinati, Democracy Disfigured: Opinion, Truth, and the People. Cambridge, MA: Harvard University Press, 2014. V. Contemporary Political Theory 1-38.

Usp. Matt Qvortrup, Referendums Around the World: The Continued Growth of Direct Democracy, Springer, 2014., p. 306; Ovid Bozd, Referenda around the World - History and Status of Direct Democracy, https://www.democracy.uci.edu/files/docs/conferences/grad/Boyd_Referenda\%20around\%20 the\%20World.pdf.

39 Simon Tormey, The Contemporary Crisis of Representative Democracy, https://www.aph.gov.au/About Parliament/. Senate/Powers_practice_n_procedures/pops/Papers_on_Parliament_66/The_Contemporary_Crisis_of_Representative_Democracy. 
... početak nečega što može postati dominantan pravac (...) političke kulture ili jednostavno nešto što je prolazna bolest koja će nestati jednako tako misteriozno kao što se je i pojavila. ${ }^{40}$

Nastupajuća kritička analiza komparativnog predstavništva stremi zaključku da politički sustavi u ustavnodemokratskim zemljama više ne odgovaraju postojećoj političkoj kulturi; takvi sustavi traže adaptaciju radi mogućeg izravnijeg uključivanja naroda u političko odlučivanje, što podrazumijeva upotrebu i takvih instrumenata kao što su institucije neposredne demokracije. Ipak, izravan poziv narodu da se koristi referendumom, građanskom inicijativom i opozivom može doći u konflikt s teorijom i praksom predstavničke vlade s kojima su građani srasli u najvećem broju razvijenih parlamentarnih demokracija. ${ }^{41}$

Ako je 20. stoljeće vrijeme u kojemu je velik broj država postao dio „demokratskog svijeta" u kojemu se, barem u načelu, poštuju ljudska prava i koji osigurava slobodu pojedinca i njegovih grupa, onda je početak 21. stoljeća vrijeme pojave postreprezentatione demokracije s procvatom referendumske participatorne demokracije. ${ }^{42}$ Istraživači referenduma navode da je na prijelazu stoljeća participatorna demokracija iskusila enormni skok; više od polovice od ukupno održanih referenduma $u$ povijesti organizirano je $u$ nekoliko posljednjih dekada. ${ }^{43}$ Naravno da je taj trend političke transformacije prema neposrednoj demokraciji otvorio niz pitanja. Koje su njene posljedice? Nalazi li se svijet na putu prema neodgovornoj tiraniji većine? Ili se nalazimo na putu prema boljoj, pravednijoj budućnosti? Itd.

7. O empirijskim pokazateljima posljedica neposredne demokracije. Komparativna istraživanja pokazala su da neposredna demokracija mijenja ustavno-politički proces predstavničke demokracije na tri važna načina: (i) zahvaljujući tome što institucije neposredne demokracije utječu na restrikciju vlasti etabliranih političara, rezultat političkog procesa bliži je preferencijama angažiranih građana; (ii) participatorni karakter neposrednog odlučivanja omogućuje biračima inicijativu prema mogućnostima informiranja i promjene

40 Richard Van Loon and Michael Whittington, The Canadian Political System: Environment, Structure and Process, McGraw Hill-Ryerson, Toronto, 1987, p. 164.

41 Nevil Johnson, "Types of Referendum", in Austin Ranney, ed., The Referendum Device, American Enterprise Institute for Public Policy Research, Washington, 1981, p. 19. Charlemagne Referendum madness-Plebiscite-pushers have got Europe's voters hooked on the cheap rush of direct democracy, https://www.economist.com/europe/ 2016/01/14/referendum-madness.

S. Tormey, op. cit., p. 4. beyond (2008 ed.). Bern: Benteli Hallwag Druck AG., p. 199. 
u odnosima između vlasti i birača; (iii) neposredna demokracija omogućuje institucionalnu promjenu i štiti pravila koja idu u korist građana. ${ }^{44}$

U dominantnom svijetu suvremene predstavničke demokracije referendumi su se intenzivnije počeli koristiti tek od sredine 19. stoljeća, najprije u Švicarskoj, a s prijelaza iz 19. u 20. stoljeće u SAD-u, a zatim i drugdje u svijetu (Italija, Lichenstein, Njemačka, Filipini...). Švicarska i SAD imaju najplodniju praksu referenduma i upravo je njihovo iskustvo omogućilo najširi uvid u njihove mane i prednosti. Upravo je to iskustvo, a posebno imajući u vidu one posljednje referendume u Ujedinjenom Kraljevstvu (2016. - referendum o povlačenju UK iz EU), Italiji (2016. - referendum o promjeni sastava i ovlasti parlamenta, podjeli vlasti između države, regija i administrativnih jedinica), Mađarskoj (2016. - referendum o kvotama EU o razmještaju emigranata), Nizozemskoj (2016. - referendum o sporazumu EU s Ukrajinom), opet podsjetilo na urgentnu potrebu odgovora na pitanje s kojim su se sučelile suvremene ustavne demokracije: - "Jesu li birači u eri tržišnih istraživanja i statistike u potpunosti svjesni razlike između referenduma i glasovanja na izborima?" Koliko se mudrosti može naći u sve ekscesivnijem korištenju referenduma?

Kako cijeniti praksu u kojoj se referendum i građanska inicijativa kao oblici izravne demokracije propagiraju građanima koji su odustali od politike, a posebno kako u praksi liječiti posljedice nastupajućeg majoritarizma i njegovih koncepcija demokracije koje ne mare puno za vrijednosti i rezultate ustavnodemokratskih pluralističkih rasprava? ${ }^{45}$

8. $\mathrm{O}$ argumentima protiv ekscesivne referendumske demokracije. Institucije neposredne demokracije (referendum, građanska inicijativa) otpočetka su kontroverza. U SAD-u je njihova primjena imala za posljedicu da se Kalifornija, koja je jedna od najbogatijih država Unije, dovede gotovo na rub upravljačkog kaosa. Bilo je situacija kada su se građani trebali izjašnjavati odjednom u dvadesetak referenduma o različitim pitanjima ${ }^{46}$. U EU je korištenje referenduma već donijelo dovoljno problema.

$\overline{44}$ Usustavljenu empirijsku građu o doprinosu institucija neposredne demokracije npr. na planu javnih troškova i poreza, efekata na proces političkog odlučivanja, pitanju "sreće građana“ itd. v. npr. Bowler, Shaun and Todd Donovan. (1998.) Demanding choices: Opinion, voting, and direct democracy. Ann Arbor: University of Michigan Press., Eichenberger, Reiner (1999.) Mit direkter Demokratie zu besserer Wirtschafts- und Finanzpolitik: Theorie und Empirie. In Adäquate Institutionen: Voraussetzung für "gute" und bürgernahe Politik? Schriftenreihe der Hochschule Speyer, ed. Hans Herbert von Arnim, 259-288. Berlin: Duncker \& Humblot., Kirchgässner, Gebhard, Lars P. Feld and Marcel R. Savioz. (1999.) Die direkte Demokratie: Modern, erfolgreich, entwicklungs- und exportfähig. Basel et al.: Helbing and Lichtenhahn/Vahlen/Beck., Gerber and Hug 2001.

45 R. Balfour, u Judy Dempsey Asks: Are Referenda Dangerous? http://carnegieeurope.eu/strategiceuro$\mathrm{pe} / ? \mathrm{Fa}=64835$.

46 Philip P. Frickey,Majority Rule, Minority Rights, and the Right to Vote: Reflections upon a Reading of Minority Vote Dilution, 3 Law \& Ineq. 209 (1985).Available at: http://scholarship.law.umn.edu/lawineq/ vol3/iss1/6. 
Najbolji su primjeri za to referendum $\mathrm{u}$ Francuskoj o prijedlogu Ustava za Europu (2005.), u Ujedinjenom Kraljevstvu Brexit (2016.), u Mađarskoj Orbanov referendum o migrantskim kvotama (2016.) itd. ${ }^{47}$ Jedno je sigurno. Bez preciznih ustavnih i zakonskih odredaba on je uvijek puko oruđe u rukama inicijatora. Poput oslobođenog duha iz boce, teško je kontrolirati njegov tijek i posljedice. Ipak, klasificirati referendum kao apsolutno opasno sredstvo izjašnjavanja naroda u suvremenim demokracijama nije realno. U vrijeme kad su suvremene demokracije suočene sa slabljenjem najjačih političkih stranaka i niskom izbornom participacijom, referendumska izjašnjavanja imaju ,potencijal rekonekcije elektorata s političkim rezultatima“. ${ }^{48}$

Koji su najčešći argumenti protiv korištenja referenduma? U ekstenzivnom istraživanju Gornjeg doma parlamenta UK (House of Lords) navedeni su sljedeći argumenti protiv korištenja referenduma: (1) referendum je taktičko sredstvo; (2) referendumom dominiraju elite; (3) referendum može imati štetan učinak na manjinske grupe; (4) referendum je 'konzervativni instrument'; (5) referendum ne rješava 'problem'; (6) referendum ne rješava kompleksna pitanja; (7) referendum najčešće ne rješava problem u pitanju; (8) birači ne pokazuju preveliku želju da participiraju u referendumu; (9) referendum je skup; (10) referendumom se ruši predstavnička demokracija. ${ }^{49}$

Na pitanje je li referendum adekvatno sredstvo za donošenje značajnih ustavnih odluka odgovarao je i Stephen Tierney u knjizi Constitutional Referendums: The Theory and Practice of Republican Deliberation (2012.). ${ }^{50}$ On formulira tri demokratska prigovora referendumima. (i) Prvi prigovor on naziva sindromom kontrole elite koji sugerira da egzekutiva ima široku diskreciju u odnosu na referendumska pravila. Takva diskrecija organizatoru referenduma omogućuje nesmetanu slobodu mani-

47 Charlemagne Referendum madness - Plebiscite-pushers have got Europe's voters hooked on the cheap rush of direct democracy, https://www.economist.com/europe/2016/01/14/referendum-madness; Ruth Fox, After four referendums in six years - two UK-wide and one each in Scotland and Wales, https://www. hansardsociety.org.uk/blog/parliamentary-democracy-or-referendums-public-attitudes-to-decision-making; Judy Dempsey, Are Referenda Dangerous?, October 12, 2016., http://carnegieeurope.eu/ strategiceurope/64835; Jan-Werner Müller, Homo Orbánicus, April 5 2018, http://www. nybooks.com/ articles/2018/04/05/homo-orbanicus-hungary/?printpage=true.

Gwendolyn Sasse, Are Referenda Dangerous? October 12, 2016, http://carnegieeurope.eu/strategiceurope/64835.

49 Referendums-Arguments for and against, www. Parliament. Uk, House of Lords, Ovdje se navode dobre strane primjene referenduma: (1) referendumi obogaćuju demokratski proces, (2) referendum može biti normativno oružje; (3) referendum može 'riješiti' određeno pitanje; (4) referendum može biti protektivno sredstvo; (5) referendum obogaćuje angažiranje građana; (6) referendum promovira glasačko obrazovanje; (7) birači su u stanju donijeti razložne odluke; (8) referendumi su popularni kod birača; (9) referendumi dopunjavaju predstavničku demokraciju.

50 Stephen Tierney, Constitutional Referendums: The Theory and Practice of Republican Deliberation (Oxford: Oxford University Press, 2012.). 
puliranja. Ako inicijativa pripada egzekutivi i nema kontrole legislature, to znači da egzekutiva nesmetano odlučuje o tome kada će i što će biti pitanje o kojem će se odlučivati na referendumu. (ii) Druga kritika referenduma odnosi se na ugrađenu tendenciju u referendumskom procesu koja agregira već unaprijed stvorena mišljenja o određenom pitanju, a ne potiče plodonosnu raspravu. Tu situaciju Tierney naziva deliberacijskim deficitom. Riječ je o tome da referendum angažira birače jedino u vrijeme glasovanja, što birači prihvaćaju bez ikakve stvarne refleksije ili kolektivne diskusije o pitanju. Po mnogima je riječ o najozbiljnijem prigovoru referendumu: nije riječ samo o reduciranom načinu odlučivanja nego i o tome da takvo odlučivanje može biti jako opasno. (iii) Treći je prigovor tzv. većinska prijetnja koja implicira da referendum predstavlja takav model većinskog odlučivanja koji ugrožava interese pojedinaca i manjina koje ne plivaju u matici. Riječ je o jednostavnom poučku. Referendumi obično prihvaćaju majoritarni model odlučivanja koji uključuje $50 \%$ glasova plus $1 \mathrm{u}$ kojem pobjednik odnosi sve i u kojemu je manjina u potpunosti predana na "milost i nemilost" većini ${ }^{51}$. Ipak, demokracija nije samo puka vladavina većine; danas postoji ustavna demokracija kao sustav koji štiti individualna prava i sustav u kojemu odluke trebaju imati što je šire moguću podršku naroda. ${ }^{52}$

Ono što nam je komparativno gradivo o praksi institucija neposredne demokracije ostavilo kao pouku jest sljedeće: Da bi se u postkriznim situacijama i vremenima kao što je naše danas uspješno primijenile institucije neposredne demokracije, potrebna je građanska kultura koja uvelike olakšava njihovu primjenu. Tamo gdje nema adekvatne društvene osnove nije moguće uspješno ostvarivati institucije referenduma i građanske inicijative. Jedan od uvjeta njihove primjene referenduma i građanske inicijative jesu situacije jasnih i oštrih podjela (npr. oko religije, kulture, jezika, financija, plaća...) koje pokazuju da nisu uvijek eksploatirane jedne te iste društvene grupe. Također se naglašava da građani ipak trebaju imati određenog povjerenja u političare s obzirom na činjenicu da oni aktualiziraju referendumsku odluku, kao što političari moraju vjerovati da će građani prilikom glasovanja donijeti razumne odluke. No to povjerenje razvija se tijekom vremena, što znači da se ne može jednostavno presaditi izvana. Konačni je zaključak da 'odsudno' pitanje skoka iz predstavničke demokracije u potpuno razvijenu neposrednu demokraciju nije ni moguće ni poželjno. ${ }^{53} \mathrm{Na}$ pravima neposredne participacije treba raditi pažljivo. Svaki referendum sadrži vlastiti rizik i to ne samo zato što svaki od njih ima svoju

\footnotetext{
51 Stephan Michel and Ignacio N. Cofone, Majority Rules in Constitutional Referendums KYKLOS,Vol. 70 - August 2017 - No. 3, 402-424.

52 Stephen Tierney, 'Should the People Decide?' Referendums in a Post-Sovereign Age, the Scottish and Catalonian Cases, Netherlands Journal of Legal Philosophy 2016 (45) 2, doi: 10.5553/NJLP/.000050, p. 99 et passim.

53

Usp. Bruno S. Frey, Alois Stutzer and Susanne Neckermann, op. cit., p. 15.
} 
vlastitu dinamiku. No kod svakog treba voditi računa prije svega o pravilima koja ga reguliraju (pitanja o kojima se odlučuje, razina vlasti na kojoj se odlučuje, izborna mehanika), kao i o širem političkom kontekstu u kojemu se odvija referendum. Uvijek ostaje konkretno pitanje predstavljaju li dramatične posljedice informacijskog vakuma i političke manipulacije prije narodnog odlučivanja osnovu moguće invalidacije referendumskog potencijala kao legitimnog dijela demokratskog arsenala.

9. Ustavnosudska kontrola neposredne demokracije. Jedan od aksioma suvremenog konstitucionalizma jest sljedeći: demokracija počiva na većinskom principu, ali $u$ isto vrijeme ustavna demokracija ne može biti čisto većinska. S obzirom na to da neograničena demokratska većina može unutar države gaziti kako hoće po individualnim pravima, dostojanstvu i interesima etničkih, vjerskih i kulturnih manjina, to znači da sam integritet demokracije traži određeni protuvećinski institucionalni mehanizam kojim bi se kontroliralo većinska posezanja i ekscese. Za potonju svrhu od velike je koristi ustavnosudska kontrola neovisnih sudaca. Konstatirajući da herojska uloga koju danas imaju ustavni suci kao zaštitnici slobode govora nepopularnih političkih ili ideoloških stajališta ili napadno diskriminirajućih stajališta u pitanjima spola, rase ili religije nije više kontroverzna, Michel Rosenfeld govori o širokoj ekspanziji sudske intervencije $\mathrm{u}$ raspravu o judicijalizaciji politike i kritici sve učestalijeg sudskog rješavanja političkih pitanja od strane sudaca koje ne izabire narod. ${ }^{54}$

Ipak, za $\boldsymbol{R}$. Hirshla evidentno je da sudsko rješavanje velikog broja najvažnijih političkih pitanja s kojima se danas susreće moderna država ne proizlazi

samo iz sudskog samouzdizanja, već i iz namjere političkih i ekonomskih elita da suštinsko odlučivanje odmaknu od nestalnosti demokratske politike. ${ }^{55}$

Imajući u vidu takvo djelovanje sudova, od interesa je postaviti pitanje je li bilo slučajeva da su sudovi kontrolirali ustavnost pojavnih oblika neposredne demokracije i na koji su način opravdavali svoje postupanje. To još više ima smisla s obzirom na činjenicu da su u posljednje vrijeme mjere neposredne demokracije (referendum, inicijativa) sve učestalije počele zadirati u problematična i složena pitanja građanskih prava i prava manjina. U SAD-u su neke istaknute države kao što su Kalifornija, Colorado, Oregon, Washington, Arizona i Florida postale pravo „ratno poprište“ sudskog razmatranja kontroverznih zahtjeva pristaša referenduma i inicijativa: o isključivoj upotrebi engleskog jezika na radnome mjestu (Arizona), oštrom sužavanju korištenja afirmativne akcije (Ka-

\footnotetext{
54 Michel Rosenfeld, Judicial Politics versus Ordinary Politics: is the Constitutional Judge Caught in the Middle?, u Forthcoming Judicial Power, (Cambridge University Press, 2018), Christine Landfried, ed., SSRN Collection.

55 R. Hirschl, The Judicialization of Mega-Politics and the Rise of Political Courts, Annual Review of Political Science 11 (2008), 93 -118 [108].
} 
lifornija), restrikcije antidiskriminacijskih zaštita koje su dodjeljivane homoseksualcima i lezbijkama (Oregon), eliminaciji beneficija u korist useljenih radnika (Kalifornija) te postavljanju granica dvojezičnom obrazovanju (Kalifornija). Svi su ti oblici neposredne demokracije bili podvrgnuti ustavnosudskoj kontroli zaštite po osnovi jednakosti i drugim osnovama. Najpoznatiji takav slučaj jest slučaj Romer v. Evans 517 U.S. 620 (1996.) u kojemu je Vrhovni sud SAD-a srušio inicijativu građana Colorada protiv prava homoseksualaca (Amandman 2). Osim Vrhovnog suda SAD-a, i drugi su se federalni i državni sudovi za rušenje antimanjinskih mjera $u$ referendumima i inicijativama koristili federalnim ustavnim argumentima. ${ }^{56}$

\section{O važnosti potvrde autoriteta Ustava i konstitucionalizma u Republici}

Hrvatskoj. Dok su klasični ustavi (ustavi diobe vlasti) promicali monopol u stvaranju opće volje, noviji ustavi (ustavi garancija prava) u procesu njene formulacije potiču natjecanje. Taj se prijelaz izravno duguje kontroli ustavnosti zakona i novoj definiciji prava jer s time u skladu sada i suci utvrđuju pravna pravila. Navodimo primjer odluke francuskog Ustavnog vijeća (Conseil Constitutionell) od 23. 8. 1985. u kojoj se utvrđuje da ",usvojeni zakon ne izražava opću volju osim ukoliko poštuje Ustav“.57 U klasičnoj Deklaraciji o pravima iz 1789. godine stoji da je „zakon izraz opće volje“. Ta promjena u definiranju prava - kretanje od afirmativnog prema negativnom (zakonodavcu) te uvođenje ustavnosti kao uvjeta - implicira i legitimizira način stvaranja opće volje. Ustavna je teorija to komentirala na sljedeći način.

Prije pojave i razvitka ustavnog prava legislativna djelatnost zastupnika bila je atribuirana izravno narodnoj volji, ali narod nije bio u stanju protestirati jer, prema ustavnoj definiciji, za njih nije bilo separatnog, neovisnog načina da

\footnotetext{
56 Vargas, Sylvia R. Lazos, Judicial Review of Initiatives and Referendums in Which Majorities Vote on Minorities' Democratic Citizenship, Ohio State Law Journal, vol. 60, no. 2 (1999), 399-555. http://hdl.handle. net/1811/64997; Vargas, Sylvia R. Lazos, Judicial Review of Initiatives and Referendums in Which Majorities Vote on Minorities' Democratic Citizenship, Ohio State Law Journal, vol. 60, no. 2 (1999), 399-555., http://hdl.handle.net/1811/64997; Robin Charlow, Judicial Review Equal Protection and the Problem with Plebiscites, 79 Cornell L. Rev. 527 (1994); Available at: http://scholarship.law. cornell.edu/clr/vol79/ iss3/4; Steven Spadijer, A Hardcore Case Against (strong) Judicial Review of Direct Democracy, University of Queensland Law Journal, Vol. 31(1), 2012, p. 55-99; Limitations on Initiative and Referendum, 3 Stan. L. Rev. 497 (1951); James D. Barnett, Judicial Review of exceptions from the Referendum, 10 Cal. L. Rev. 371 (1922);; Available at: http://scholarship.law.berkeley.edu/californialawreview/vol10/iss5/1; Stephan Michel and Ignacio N. Cofone, Majority Rules in Constitutional Referendums KYKLOS, Vol. 70 - August 2017 No. 3, 402-424; Comment, Judicial Review of Laws Enacted by Popular Vote, 55 Wash. L. Rev. 175 (1979); Constitutional Constraints on Initiative and Referendum, 32 Vand. L. Rev. 1143 (1979); Judicial Review of Initiative Constitutional Amendments, 14 U.C. Davis L. Rev. 461 (1980); Bell, The Referendum: Democracy's Barrier to Racial Equality, 54 Wash. L. Rev 1, 22-28 (1978); Laurence Tribe and Jesse Choper in J. Choper, Y. Kamisar \& L. Tribe, The Supreme Court: Trends And Developments (1981-82), at 242-43 
imaju volju drugačiju od one koju su izražavali njegovi zastupnici. S ustavnom revizijom predstavnici su još kvalificiraniji izražavati volju naroda, mada fuzija dviju volja više nije bila moguća. Suci su, kontrolirajući ustavnost zakona pomoću povelje o temeljnim pravima koju stvaraju i koja definira prostor za autono$\mathrm{mnu}$ reprezentaciju narodnog suvereniteta, uvijek u poziciji da u zakonima koje zastupnici usvajaju pokažu („u svjetlu Ustava“ - kako su to rekli u Ustavnom vijeću) i da - ako je to nužno - poduzmu korake protiv bilo kakvog jaza između ustavnih zahtjeva i njihovih tumačenja. ${ }^{58}$

Međusobno natjecanje u stvaranju opće volje između legislature i Suda uključuje raspravu kao nuždan operativni princip. I doista, kada opća volja nije situirana u jednoj instituciji, kada volja predstavnika nije sama po sebi opća volja, kada je opća volja konstruirana komparacijom tekstova koje donose predstavnici prema ustavnim zahtjevima, onda opća volja jedino može biti produkt razmjene argumenata između različitih aktera u stvaranju zakona.

U lancu argumentacije suci su samo jedna veza. Oni interveniraju u određeno vrijeme kako bi svojom odlukom potvrdili značenje ustavne odredbe... Kontrolirajući ustavnost zakona, suci ne vladaju: u kompetitivnom sustavu formiranje opće volje oni su regulirajuće tijelo. ${ }^{59}$

U suvremenosti u kojoj je sve više ustava oživljeno ustavnom revizijom ustav postaje instrument koji je zajednički svim pojedincima, oni u njemu prepoznaju svoje posebnosti i vlastiti ritam, ali i podijeljene i zajedničke vrijednosti, koje $J$. Habermas naziva ustavnim patriotizmom. U ustavima moderni razočarani pojedinac može rekonstruirati zajednički identitet. U njegovu tekstu sve pojedinosti dobivaju fiksiranu točku u kojoj se aktivnosti pojedinaca mogu artikulirati, promišljati, kritizirati i presuđivati. Jer, za svakoga od nas slika ustava sadrži

... više želja i obećanja od onih u objektivitetu: jednakost između muškaraca i žena, osobna sloboda, bratstvo (između ostalih stvari) su karakteristike koje se u odnosu na pravo priželjkuju, sanjaju, oni su nada, mada se negiraju u svakodnevnom svijetu isključivanja, nejednakosti, nepravde i dominacije. A upravo taj raskorak koji postoji između ustavnih obećanja na jednakost, slobodu i solidarnost i mizerije svijeta potiče mogućnosti kritike takve stvarnosti i političke akcije koje streme promijeni. Zato ustavni identitet ostaje ispred nas, kao nešto što dolazi, nešto što je na samom horizontu zahtjeva demokracije. ${ }^{60}$ 2008., p. 18; usp. Michel Rosenfeld, Judicial Politics versus Ordinary Politics: Is the Constitutional Judge Caught in the Middle? Christine Landfried, ed., Judicial Power (Cambridge University Press 2018) 
Ima li dakle ustavni sudac legitimitet kontrolirati zakon koji su usvojili predstavnici naroda? Je li njegova uloga preveniranje većinske volje? Vjerujemo da u nizu brojnih i autoritativnih eksplikacija mjesta i uloge današnjega komparativnog ustavnog sudstva navedena stajališta pokazuju da Ustav nije prepreka demokratskom izražavanju već prije uvjet njegova bogatstva i dubine. To stajalište vrijedi, dakako, i za Ustavni sud Republike Hrvatske kao autoritativnog tumača Ustava Republike Hrvatske. Taj se zaključak može pogotovo primijeniti za one slučajeve kontrole ustavnosti kada se izravnim demokratskim sredstvima odlučivanja želi na bilo koji način ugroziti bilo koja postojeća manjinska prava. Budući da smo svjedoci vremena u kojemu moderna politika i političko natjecanje potiču ekscese, upravo iz tih razloga

... sudovi moraju osigurati potrebno ograničenje, podsjetiti nas na naše ideale i vrijednosti, i tražiti da kao javni građani donosimo samo one zakone koji reflektiraju pravu mjeru nas samih. ${ }^{61}$

O trendu jačanja ustavnosudske komponente razvijenih demokracija svjedoče i aktualne konfrontacije političkog i legalnog konstitucionalizma unutar kojih se razvijaju i razrješavaju problemi koje nosi referendumsko izjašnjavanje naroda.

11. O ustavnosti recentnih referendumskih inicijativa $\mathbf{u}$ Republici Hrvatskoj. Posvuda po svijetu frustrirani se građani zbog neučinkovitosti svojih izabranih zastupnika sve više okreću prema svojevrsnim do it by yourself modelima vlasti. Birališta se sve češće koriste radi izmjena i dopuna ustava, referenduma, inicijativa i opoziva koji su nekada isključivo pripadali domeni parlamentarnih tijela. ${ }^{62}$ Ni Hrvatska po svemu nije izuzetak. I kod nas je sve prisutnije uvjerenje da su građani isto toliko normativno kompetentni koliko i izabrani zastupnici. Ipak, rastuće zanimanje na referendume i inicijative nosi u sebi imanentnu prijetnju općenito prema ugrozi individualnih prava, a posebno potiče krizu prava za nacionalne, rasne i druge „diskretne“ manjine. Stoga se s pravom postavlja pitanje mogu li sudovi koristeći postojeće ustavne principe uz potvrdu legitimnosti institucija neposredne demokracije zaštititi manjinska prava od moguće zloupotrebe većine.

(Forthcoming), Cardozo Legal Studies Research Paper No. 540, 24 Pages Posted: 17 Jan 2018 Last revised: 12 Mar 2018; https://papers.ssrn.com/sol3/ papers. cfm?abstract_id=3099752; Gerhard Casper, "Guardians of the Constitution," 53 Southern California Law Review 773 (1980).

Sylvia R. Lazos, Judicial Review of Initiatives and Referendums in Which Majorities Vote on Minorities' Democratic Citizenship, Ohio State Law Journal, vol. 60, no. 2 (1999), 399-555. 
Pred istim izazovom može biti i Ustavni sud Republike Hrvatske da mu se kojim slučajem Hrvatski sabor obrati s pitanjem provjere ustavnosti pitanja kojima bi jedna građanska inicijativa pokušala još jednom iskoristiti mogućnost referendumske promjene Ustava $\mathrm{RH}$. U konkretnom slučaju riječ je o dva referendumska pitanja. Prvo referendumsko pitanje glasi:

\section{Jeste li za to da se članak 72. Ustava Republike Hrvatske mijenja i glasi:}

'Hrvatski sabor ima najmanje 100, a najviše 120 zastupnika, koji se, na temelju općeg i jednakog biračkog prava, biraju neposredno tajnim glasovanjem. Pripadnici nacionalnih manjina biraju najviše šest zastupnika u Hrvatski sabor.

Zastupnici se u Hrvatski sabor, osim zastupnika nacionalnih manjina, biraju prema sustavu razmjernog predstavništva. Birač može glasovati za jednu od predloženih lista kandidata i može označiti do tri kandidata koji imaju prednost pred ostalim kandidatima na listi za koju je glasovao (preferirani glas). Izabrani kandidati s pojedine liste utvrđuju se isključivo na temelju najvećeg broja preferiranih glasova.

U svakoj izbornoj jedinici u Republici Hrvatskoj bira se najmanje 15 zastupnika. Izborne jedinice ne smiju dijeliti zakonom utvrđena područja Grada Zagreba i županija Republike Hrvatske. Broj zastupničkih mjesta rasporedit će se među izbornim jedinicama na temelju izračuna odnosa broja birača u svakoj izbornoj jedinici i ukupnog broja birača u Republici Hrvatskoj.

Pravo na sudjelovanje u diobi zastupničkih mjesta u izbornoj jedinici ostvaruju kandidacijske liste koje su na izborima dobile najmanje 4 posto važećih glasova birača.

Birači na izborima mogu glasovati: na biračkom mjestu, dopisnim ili elektroničkim putem. Drugo je pitanje:

Jeste li za to da se iza članka 72. Ustava Republike Hrvatske doda članak 72.a koji glasi:

'Zastupnici nacionalnih manjina odlučuju o svim pitanjima iz nadležnosti Hrvatskoga sabora, osim o povjerenju Vladi i donošenju državnog proračuna. ${ }^{163}$

63 Kraj 2018. pokazuje sljedeće stanje događaja: Građanske inicijative Narod odlučuje i Istina o Istanbulskoj nisu uspjele prikupiti potreban broj od 374.740 valjanih potpisa da bi se raspisao referendum. Prema navodima premijera A. Plenkovića i ministra uprave L. Kuščevića, Istina o Istanbulskoj predala je 390.916 potpisa, ispravna su bila 345.942, a neispravna 44.974. Narod odlučuje za prvu referendumsku inicijativu prikupio je 412.325, od kojih je bilo ispravno 371.450 , a neispravno 40.875 . Za drugu inicijativu prikupili su 407.835, od kojih je bilo ispravno 367.169 , a neispravno 40.666 . Obje inicijative potpise su prikupljale od 13. do 27. svibnja. Vlada je 2. kolovoza zadužila Ministarstvo uprave za koordinaciju aktivnosti vezanih za provjeru broja i vjerodostojnosti svih potpisa iz zahtjeva za raspisivanje državnih referenduma te Ministarstvo uprave i Ministarstvo unutarnjih poslova za provjeru zakonitosti prikupljanja potpisa. Iako je Vlada RH preko Ministarstva uprave zaključila da nema dovoljno potpisa koji inicijatorima jamči pokretanje referendumskog postupka za izmjenu 
Prema važećim pozitivnim propisima, Ustavni sud Republike Hrvatske, potaknut zahtjevom Hrvatskog sabora, imao bi u ovom slučaju dakle utvrditi:

(...) je li sadržaj referendumskog pitanja u skladu s Ustavom i jesu li ispunjene pretpostavke iz članka 86. stavaka 1. -3 . Ustava Republike Hrvatske za njegovo raspisivanje. ${ }^{64}$

U nastavku ukazujemo zašto, po našem mišljenju, sadržaj pitanja (1) i (2) nije u skladu sa slovom i duhom (vrednotama) Ustava Republike Hrvatske. Mišljenja smo da tako predložena pitanja nisu sukladna ustavnim vrednotama jednakosti, poštivanja prava čovjeka i vladavine prava, i to prije svega zbog ustavno-nomotehničkih razloga koji otvaraju probleme proceduralne vladavine prava (pitanje br. 1) i, drugo, zbog ustavno-supstancijalnih razloga, prije svega u odnosu na ustavne odredbe o jednakosti i poštivanju ljudskih prava (pitanje br. 2). ${ }^{65}$

Ustava RH, inicijatori ne posustaju. Najavljuju se ustavne tužbe. Usp. Izvješće Povjerenstva o provjeri broja i vjerodostojnosti potpisa birača iz zahtjeva za raspisivanje državnog referenduma građanskih inicijativa "Narod odlučuje“ $i$ "Istina o Istanbulskoj”, objavljeno: 17. 10. 2018.; https://uprava.gov.hr/vijesti/izvjescepovjerenstva-o-provjeri-broja-i-vjerodostojnosti-potpisa-biraca-iz-zahtjeva-za-raspisivanje-drzavnog-referenduma-gradjanskih-inicijativa-narod-odlucuje-i-istina-o-istanbulskoj/14813; N. Zagorac, Plenković: Ni jedna inicijativa za referendum nema potpise Vlada Republike Hrvatske danas će na redovnoj sjednici raspravljati o prijedlogu mirovinske reforme, ali i o potpisima referendumske inicijative; 24 sata, srijeda, 17.10.2018, https: // www. 24sata. hr/news/plenkovic-ni-jedna-inicijativa-za-referendum-nema-potpise-595532 - 24sata.hr; Vlada: Nema dovoljno potpisa za referendume inicijativa Narod odlučuje i Istina o Istanbulskoj, 17/10/2018, Lider/Hina, https: //lider.media/aktualno/biznis-i-politika/hrvatska/ vlada-nema-dovoljno-potpisa-za-referendume-inicijativa-narod-odlucuje-i-istina-o istanbulskoj/; https://www.tportal.hr/ vijesti /clanak/otkriveno-kako-ce-glasiti-referendumska-pitanja-inicijativenarod-odlucuje-20180428. Neovisno o daljnjem tijeku inicijative, u tekstu se izlažu argumenti u prilog ustavne vrednote jednakosti i vladavine prava kao vrhovnog telosa Ustava Republike Hrvatske i same okosnice njegova ustavnodemokratskog integriteta.

Članak 95. Ustavnog zakona o Ustavnom sudu Republike Hrvatske: „(1) Na zahtjev Hrvatskoga sabora Ustavni sud će, u slučaju kad deset posto od ukupnog broja birača u Republici Hrvatskoj zatraži raspisivanje referenduma, utvrditi je li sadržaj referendumskog pitanja u skladu s Ustavom i jesu li ispunjene pretpostavke iz članka 86. stavka 1. do 3. Ustava Republike Hrvatske za njegovo raspisivanje. (2) Odluku Ustavni zakon o Ustavnom sudu Republike Hrvatske iz stavka 1. ovoga članka Ustavni sud će donijeti u roku od 30 dana od dana zaprimanja zahtjeva." Ispravno je čl. 87., a ne 86. O ispravnoj enumeraciji ustavnih članaka usp. NN 5/2014 (15.1.2014.), Odluka u povodu okončanja postupka nadzora nad ustavnošću i zakonitošću provođenja držanog referenduma održanog 1. prosinca 2013., na kojem je članak 62. Ustava Republike Hrvatske dopunjen novim stavkom 2., broj: SuP-O-1/2014. od 14. siječnja 2014.

Članak 3. Ustava RH.: „Sloboda, jednakost, nacionalna ravnopravnost i ravnopravnost spolova, mirotvorstvo, socijalna pravda, poštivanje prava čovjeka, nepovredivost vlasništva, očuvanje prirode i čovjekova okoliša, vladavina prava i demokratski višestranački sustav najviše su vrednote ustavnog poretka Republike Hrvatske i temelj za tumačenje Ustava." 
11. 1. Proceduralni zahtjevi vladavine prava kao razlozi nesukladnosti pitanja br. 1 s Ustavom Republike Hrvatske (čl. 3. vladavina prava - proceduralni aspekt):

(i) Procedure igraju ključnu ulogu u izgradnji legitimnosti ustavnopravnog poretka. Proceduralni aspekt vladavine prava odnosi se na institucionalne procedure koje oblikuju pravni sustav. Kompleks uključuje sudove, ali uz njih i bilo koje druge institucije koje sadrže određene elemente legalne procedure. Proceduralne karakteristike posebno su važne baš za uspostavu izbornog sustava kao sastavnog dijela ustavnodemokratske vladavine prava. U slučaju referendumskog pitanja br. 1 kojim se želi izmijeniti i dopuniti čl. 72. Ustava pojam proceduralne vladavine prava omogućuje zaključak o nesuglasnosti pitanja i njegovih intencija s navedenom ustavnom vrednotom, prije svega zbog načina na koji se takav sustav procedura i pravila za referendumsko narodno odlučivanje mora konstruirati i administrirati da bi bio učinkovit, a $u$ isto vrijeme i ostati ono što mu je imanentna namjera da bude. ${ }^{66}$

(ii) Na važnost proceduralne vladavine prava ukazuje Kodeks dobre referendumske prakse Venecijanske komisije Vijeća Europe koji, radi sprječavanja nezakonitih referenduma, određuje da pravni tekstovi koji su proceduralno ili supstancijalno „nevažeći“ ne smiju biti predmet referendumskog izjašnjavanja. ${ }^{67}$

(iii) Sukladno Zakonu o referendumu i drugim oblicima osobnog sudjelovanja $u$ obavljanju državne vlasti i lokalne i područne samouprave, čl. 8.a Odluka Organiza-cijskog odbora da se pristupi izjašnjavanju birača o potrebi da se zatraži raspisivanje referenduma treba sadržavati ,jasno formulirano pitanje o kojemu se traži raspisivanje izbora". 68

(iv) Oblikovanje referendumskog pitanja općenito je jedno od najvažnijih nomotehničkih problema u referendumskom projektu. Ekspertna istraživa-

$\overline{66}$ Lon Fuller, The Morality of Law (New Haven: Yale University Press, 1969), 162., cit. pr. Jeremy Waldron, The Rule of Law and the Importance of Procedure, Electronic copy available at: http://ssrn.com/ abstract $=1688491$ October 2010.

Code of Good Practice On Referendums adopted by the Council for Democratic Elections at its 19th meeting (Venice, 16 December 2006) and the Venice Commission at its 70th plenary session (Venice, 16-17 March 2007).

Zakon o referendumu... članak 8.b: „(1) Organizacijski odbor donosi odluku da se pristupi izjašnjavanju birača o potrebi da se zatraži raspisivanje referenduma. (2) Odluka iz stavka 1. ovoga članka sadrži: - jasno formulirano pitanje o kojem se traži raspisivanje referenduma, -- rok unutar kojeg će se sakupljati potpisi birača koji traže raspisivanje referenduma koji ne može biti duži od 15 dana. (3) Odluka da se pristupi izjašnjavanju birača o potrebi da se zatraži raspisivanje referenduma objavljuje se u dnevnom tisku i drugim sredstvima javnog priopćavanja." 
nja pokazala su da način oblikovanja (fraziranja) pitanja ima bitne implikacije na konačnu odluku birača. Otuda je razumljiva pretpostavka o odgovornosti organizatora da referendumsko pitanje bude razumljivo, a ne komplicirano i konfuzno. ${ }^{69}$

Međutim, referendumsko pitanje br. 1 daleko je od toga da zadovolji postulat kratkog, jednostavnog i razumljivog pitanja. Upravo suprotno. Pitanje br. 1 suštinski pripada materiji ustavnog izbornog prava kao jednom od najsloženijih područja ustavnosti, a kako je u svojoj izvedbi prekomplicirano i nečitko formulirano za većinu birača, to ono nesumnjivo dovodi u pitanje njihovu definitivnu slobodu opredjeljenja po savjesti i kompetenciji. Prije će biti da u predreferendumskom ozračju takva situacija izlaže birače izravnoj manipulaciji organizatora referenduma (različitim političkim elitama).

Konkretno, pitanje br. 1 sadrži prijedlog izmjena i dopuna čl. 72. Ustava Republike Hrvatske, ali njegova nomotehnička formulacija prosječnom biraču u situaciji referendumskog take it or leave it (biti ili ne biti) odlučivanja ničim ne otkriva uzročno-posljedičnu vezu između apstraktnog načela o narodnom suverenitetu i operativnih tehničkodetaljnih formula o utvrđivanju većine koja pobjedom na izborima dobiva pravo izbora vlade i upravljanja državom. Referendum se ne može održavati u vakuumu, dakle u situaciji koju generalno karakterizira nepoznavanje tehničkih detalja izbornog procesa i njegovih posljedica na strani prosječnog birača. Ono što je prikladno za raspravu u ustavotvornom forumu koji raspravlja i traži najbolji detaill tecnico nije i ne može automatski biti va banque predmet odlučivanja na referendumu. Političkim referendumskim odlukama ustavotvornog ranga treba prethoditi „,autentična razmjena mišljenja“. Tu autentičnu deliberaciju politički filozof John Rawls zvao je ,javnim razumom“.

Prema tom principu - „narod koji je angažiran u donošenju odluka trebao bi se na autentičan i pošten način angažirati javno s drugim ljudima, biti pripravan braniti svoja stajališta ali i biti otvoren na uvjeravanja argumentima drugih" ${ }^{\prime 70}$.

Poučan i školski primjer razumljivog pitanja navodi S. Tierney u jednom od svojih recentnijih tekstova u kojemu analizira više aspekata zadnjeg velikog referenduma u Škotskoj. Kada je škotska vlada originalno predložila pitanje: - „Da li se slažete da Škotska bude neovisna zemlja? Da/Ne" odlučila ga je poslati na reviziju izbornoj komisiji. Proces je bio završen brzo jer je Komisija sugerirala Vladi

69 The Use and Design of Referendums - An International IDEA Working Paper Presented at Seminar on the Referendum in Costa Rica, Co-sponsored by International IDEA and the Supreme Election Tribunal of Costa Rica 25 May 2007 by Andrew Ellis Director of Operations International IDEA Stockholm, Sweden.

70 Stephen Tierney, 'Should the People Decide?' Referendums in a Post-Sovereign Age, the Scottish and Catalonian Cases, Netherlands Journal of Legal Philosophy, 2016 (45) 2, doi: 10.5553/NJLP/.000050. 
promjenu pitanja. Izborna je komisija naime zauzela stajalište da predloženo pitanje nije neutralno jer bi fraza - Da li se slažete...? mogla povesti ljude da odgovore s "Da“. Umjesto toga predložili su pitanje: „Treba li Škotska biti neovisna zemlja? Da/Ne." Sugestiju je Vlada prihvatila, pa je novo pitanje bilo uključeno u Zakon o škotskom referendumu (2013.).

Izborna komisija kazala je i da jasnoću pitanja ne određuje samo sintaksa već i sadržaj prijedloga o (neovisnosti). - „Jasnoća o tome na koji će se način odrediti pojmovi o neovisnosti pomogla bi biračima razumjeti na koji se način prije samog glasovanja na referendumu suprotstavljaju uzajamno suprotstavljeni zahtjevi referendumskih strana.“ Tierney skreće pažnju na to da se radi o vrlo zanimljivom komentaru jer reflektira zahtjev o tome da je punina raspravljajućeg procesa moguća tamo gdje birači znaju o čemu glasuju. A doprinos tome svakako je bila odluka škotske Vlade da 2013. godine objavi Bijelu knjigu o viziji neovisnosti i Nacrt Zakona o neovisnosti koji su trebali položiti temelje privremenog i stalnog ustavnog dokumenta neovisne Škotske. ${ }^{71}$

11. 2. Supstancijalni razlozi nesukladnosti pitanja br. 2 s Ustavom Republike Hrvatske (jednakost, čl. 3., poštovanje prava čovjeka, čl. 26.). Za razliku od prvog referendumskog pitanja koje je „primjer složenog višeznačnog omnibus pitanja“ $(\mathrm{S} . \mathrm{Sokol})^{72}$, drugo je pitanje formulirano relativno jasno i precizno, pa bi utoliko bilo - „prikladno za referendumsko odlučivanje, kad ne bi bilo neustavno“. ${ }^{73} \mathrm{Na}-$ ime, ovom se dopunom Ustava ograničava pravo zastupnicima nacionalnih manjina da odlučuju o povjerenju Vladi i donošenju državnog proračuna. Suštinski drugo referendumsko pitanje uvodi novu kategoriju zastupnika sa smanjenim ustavnim pravima u odnosu na zastupnike većinskog naroda. Lako je zaključiti da je to referendumsko pitanje nesukladno ustavnim odredbama o jednakosti (čl. 3., čl. 14., čl. 15.) i poštivanju prava čovjeka. (čl. 3., čl. 26.).(i) Drugo referendumsko pitanje nije sukladno s ustavnim određenjem jednakosti (čl. 3., 14., 15. Ustava RH). Parlament kao predstavničko i zakonodavno tijelo reflektira državnu populaciju i njenu svekoliku različitost. U tom smislu parlamenti danas nastoje osigurati različitost svog sastava, uključujući jednake mogućnosti za žene, etničke manjine, razne političke i vjerske grupe, kao i za ljude s poteškoćama u razvoju. Iako ta nastojanja uključuju uvođenje novih mjera kako bi politički život za te grupe bio

\footnotetext{
71 Stephen Tierney, op. cit., p. 109 et passim.

72 Tako doajen ustavnog prava kod nas zaključuje da je „prvo referendumsko pitanje inicijative ‘Narod odlučuje' izrazit primjer složenog višeznačnog omnibus pitanja... i kao takvo potpuno neprikladno da bi se o njemu odlučivalo na referendumu." S. Sokol, Potrebne su nam žurne ustavne promjene, Jutarnji list, 14. 7. 2018., str. 32. 
što atraktivniji, temelj prava i dužnosti zastupnika nalazi se u klasičnom pravu slobode izražavanja koje pripada svim zastupnicima bez razlike.

Zastupnici mogu ispunjavati svoje ustavne funkcije jedino ako postoje čvrste garancije njegove slobode misli i izražavanja. Bez slobode govora uime svojih birača te otvorene kritike vlade, rad parlamenta bio bi uvelike obezvrijeđen. Politički govor zastupnika u parlamentu štite brojni međunarodni instrumenti o ljudskim pravima. Posebno se to odnosi na njihovo pravo angažiranja u parlamentarnim debatama i glasovanja o politici vlade kao i drugim pitanjima bez ikakvih zapreka ili straha od represalija. Takvu posebnu zaštitu prije svega odražavaju ustavni ili zakonski dokumenti te parlamentarni poslovnici svake konkretne zemlje. ${ }^{74}$

U komparativnoj političkoj teoriji koja podupire ustavnodemokratska uređenja problem zaštite manjine ide do Federalističkih spisa (1787.) A. Hamiltona, J. Jaya i J. Madisona. Utemeljitelji američke ustavnosti dokazivali su da odluke većine mogu imati problematični efekt na prava (političke) manjine, jer će većina odlučivati u vlastitom interesu, što može uključivati i povredu prava manjine. Preciznije, opća volja ne mora uvijek biti jednaka mišljenju većine. Imajući u vidu potrebu o tome da je zaštita građanskih i manjinskih prava važan element svake demokratske države, ta bi prava trebala uživati bolju zaštitu kroz sustav kontrola i provjera negoli putem neposrednog referendumskog građanskog izražavanja. Riječ je o konstitucionaliziranom sustavu stabilnih teža i protuteža, a ne nestalnoj i povodljivoj politici većine prema manjinama. Ta se zaštita proteže i na predstavnike različitih manjina $u$ predstavničkom tijelu nacije (političkih, etničkih, rasnih...). Njeni zastupnici uživaju sva politička prava kao i drugi zastupnici u parlamentu. Zaštitu jednakih prava danas posebno uživaju pripadnici nacionalnih manjina kao posebno ranjivih društvenih grupa. Osim Ustava, o njihovim pravima jednakosti posebno govori Ustavni zakon o pravima nacionalnih manjina, Poslovnik Hrvatskog sabora itd.

Najvažnije je međutim to da -

ustavno i parlamentarno pravo Republike Hrvatske ne pravi supstancijalnu razliku između svojih zastupnika jer bi to bilo suprotno konstitucionaliziranim načelima konstitucionalizma, reprezentacije i jednakosti. ${ }^{75}$

U referendumskom pitanju br. 2 stoji dakle da: - „Zastupnici nacionalnih manjina odlučuju o svim pitanjima iz nadležnosti Hrvatskoga sabora, osim o

74 Human Rights and Parliaments: Handbook for Members and Staff, London 2011., p. 173 et passim.

75 A. Bačić, Ustavnost promjena Ustavnog zakona o pravima nacionalnih manjina i izbornog zakona, Političke analize, 8/2011, str. 44-52. 
povjerenju Vladi i donošenju državnog proračuna." Imajući u vidu već izloženo, možemo zaključiti da je i to pitanje u dramatičnom nesuglasju s odredbama Ustava Republike Hrvatske (čl. 3., čl. 14., čl. 26. te nizom odredaba iz dijela IV. Ustava koji određuje ustrojstvo državne vlasti: Hrvatski sabor, npr. čl. 72., 75., 76., položaj, prava i obveze zastupnika itd.).

Međutim, najvažnije je da predlagači referendumskog pitanja eliminacijom zastupnika iz redova nacionalnih manjina iz mogućnosti odlučivanja o povjerenju Vladi i donošenju državnog proračuna ne samo da ultimativno idu protiv ustavnog načela jednakosti (svih zastupnika) nego $\mathrm{k}$ tome još flagrantno i ignorantski odbacuju dosegnute standarde ustavnih teža i protuteža (pravo zastupnika da kontroliraju vladu...) te ustavnog parlamentarizma, odnosno prije svega prava zastupnika na slobodu izražavanja misli o dva najvažnija pitanja ustavno-političkog života nacije: pravu na formiranje i raspuštanje vlade te pravu na odlučivanju o državnim prihodima i rashodima iz kojeg je i nastao moderni parlament. Sapienti sat!

(ii) Drugo referendumsko pitanje nije sukladno s ustavnim određenjem o poštovanju prava čovjeka (čl. 3.), a posebno s čl. 38. Ustava koji

- jamči slobodu mišljenja i izražavanja misli. / Sloboda izražavanja misli obuhvaća osobito slobodu tiska i drugih sredstava priopćavanja, slobodu govora i javnog nastupa i slobodno osnivanje svih ustanova javnog priopćavanja...

Predlažući referendumsko pitanje s uskratom prava na glasovanje o Vladi i proračunu zastupnicima iz redova nacionalnih manjina, inicijatori i predlagači referenduma diskvalifikacijom jednog broja zastupnika Hrvatskog sabora objektivno potiču bojazan od tiranije većine koja se uvijek javlja kao popratni efekt primjene institucija neposredne demokracije na manjinska i građanska prava. Takva prijetnja tiranijom većine objektivni je izvor nepoštivanja prava čovjeka, posebno pripadnika nacionalnih manjina. ${ }^{76}$

Iako su dosadašnja komparativna empirijska istraživanja o efektima neposredne demokracije na manjinska prava koncentrirana uglavnom na (dvije) zemlje koje su relativno najviše prakticirale referendumsko izjašnjavanje - Švicarsku i SAD ipak se rezultati mogu koristiti orijentacijski. Posebno kad imamo u vidu da je riječ o zemljama „razvijene ustavne demokracije“. U Švicarskoj se neposredna demokracija prakticira na svim razinama vlasti, a u SAD-u se efekt neposredne demokracije najviše istraživao komparacijom demokratskih i nedemokratskih država. Utjecaj neposredne demokracije analizirao se na primjeru poštivanja prava supružnika istog spola, prava na abortus, zahtjeva za roditeljskim odobrenjem prava na poba-

76 Kohylova Katarina, Referenda on Human Rights - The example of LGBTI Rights, JAMM04 Master Thesis International Human Rights Law, Faculty of Law, Lund University, 2015. 
čaj maloljetnica, English-only propisa koji predviđaju engleski jezik kao jedini jezik u upotrebi za postupanje države u saveznim jedinicama, zahtjeva o English-only kao jedinom jeziku podučavanja u školama, afirmativne tužbe $u$ korist rasnih ili etničkih manjina, priznavanje vjerskih manjina, građanskih prava, stanovanja i smještaja, mjere za desegregaciju u školama, mjere protiv AIDS-a, istospolnog braka itd.

U SAD-u su referendumi i inicijative koje su imale namjeru povećati zaštitu prava čovjeka i manjina najčešće odbijani. U Švicarskoj su na referendumima bili nešto skloniji manjinama. Ipak, studije su pokazale negativni indirektni efekt institucija neposredne demokracije na „poseban tip manjinskih grupa“ koje su uglavnom pripadale pod službeno priznanje muslimanskih zajednica. ${ }^{77}$

Drugo referendumsko pitanje (br. 2) ne samo da na općenit način ugrožava poštivanje prava čovjeka kao ustavnu vrednotu (čl. 3. Ustava) nego isto tako predstavlja prijetnju slobodi misli i izražavanja zastupnicima iz redova nacionalnih manjina. Sloboda misli i izražavanja temeljno je ljudsko pravo. Kad je riječ o zastupnicima Hrvatskog sabora, njihova sloboda misli i izražavanja o pitanjima iz nadležnosti Hrvatskog sabora pretpostavka je ustavno-demokratskog funkcioniranja političke igre $\mathrm{u}$ parlamentu.

Nadalje, pitanje br. 2, time što uskraćuje pravo zastupnicima nacionalnih manjina da glasuju o povjerenju Vladi i državnom proračunu, izravno diskriminira tu grupu zastupnika. Riječ je o formulaciji izravne diskriminacije kako je definiraju pravo ECHR-a i EU. Prema čl. 2. Direktive o rasnoj jednakosti, posredna diskriminacija događa se -,,kad se jedna osoba tretira s manje pogodnosti nego druga, tretirala se je ili bi se tretirala u usporedivoj situaciji po osnovi rasne ili etničke pripadnosti“. Europski sud za ljudska prava (ECtHR) koristi formulaciju, koja se zasniva na identificirajućim karakteristikama, prema kojoj mora postojati razlika u tretiranju osoba u sličnim, ili značajno sličnim situacijama.

Imajući to na umu, može se zaključiti da se neposredna diskriminacija događa kad se pojedinac tretira nepovoljnije u usporedbi s drugima koji su u sličnoj situaciji, ili su u njoj bili, ili će biti, a razlog za to jest određena posebna karakteristika (etnička, vjerska, spolna... pripadnost). ${ }^{78}$

Od bitnog značenja za izravnu diskriminaciju u pitanju br. 2 jest razlika u tretmanu kojemu je pojedinac (zastupnik) podvrgnut, pa se na taj način dokaz

\footnotetext{
77 Daniel Bochsler and Simon Hug, How minorities fare under referendums. A cross-national study, Paper prepared for presentation at the ECPR General Conference Potsdam 10-12 September 2009.

Sve su se države EU pridružile Europskoj konvenciji o ljudskim pravima, koja je usko povezana s pravom EU. Članak 14. ECHR-a zabranjuje diskiminaciju jedino u odnosu prema vršenju nekog drugog prava garantiranog Ugovorom, dok nediskriminacijsko pravo EU o zabrani diskriminacije stoji samostalno, mada ograničeno u posebnim kontekstima, poput zapošljavanja. Ipak, prema Protokolu 12 ECHR-a, i zabrana diskriminacije postaje samostalno pravo.
} 
o „nepovoljnom tretmanu“ - njemu se naime uskraćuje pravo glasovanja o povjerenju Vladi i državnom proračunu kao ekstenzija slobode misli i izražavanja - može smatrati prvom osobinom izravnog diskriminiranja.

Sve nas to upućuje na diskriminatorni karakter referendumske inicijative $\mathrm{u}$ pitanju br. 2, stoga Ustavni sud treba jednostavno ocijeniti kao retrogradni pokušaj diskriminiranja onih zastupnika Hrvatskog sabora koji predstavljaju respektivne nacionalne manjine u Republici Hrvatskoj. Treba još jednom podsjetiti kako ECHR u svom čl. 14. predviđa opću zabranu diskriminacije koja garantira jednaki tretman u uživanju svih drugih prava u Konvenciji. Protokol 12. (2000.) Konvencije širi doseg zabrane diskriminacije garantirajući jednakost u uživanju bilo kojeg prava (uključujući i prava iz nacionalnog zakonodavstva). Stvoren iz želje da ojača zaštitu protiv diskriminacije, ta je jednakost u uživanju bilo kojeg prava ključni element zaštite, odnosno poštovanja ljudskih prava, pa tako i slobode mišljenja i izražavanja zastupnika nacionalnih manjina. ${ }^{79}$

12. Zaključna napomena: Na dan proglašenja Ustava Republike Hrvatske 22. prosinca 1990. dr. Franjo Tuđman u svom je prvom državničkom govoru u sabornici govorio da je većina građana Hrvatske na plebiscitaran način dala:

... svoj glas za slobodnu, demokratsku i suverenu hrvatsku državu i zato je Ustav, koji danas svečano proglašujemo, izražaj njihove volje, potvrda nacionalnoga suvereniteta hrvatskog naroda i ozbiljenje ustavno-politčkoga mandata koji smo od naroda dobili na izborima. ${ }^{80}$

U obraćanju zastupnicima Hrvatskog sabora, predsjedniku i ministrima hrvatske Vlade i drugim uzvanicima i gostima predsjednik Tuđman tada je s dubokim uvjerenjem također naglašavao da je

... Novi Ustav Republike Hrvatske svojim (...) sadržajem u cjelini izražaj (...) europske konstante hrvatske državne misli i ustavnopravne zbilje. U tom smislu, on je ne samo pravni već i institucionalno vrijednosni temelj usklađivanja svekolikoga hrvatskoga pravnoga poretka s europskim pravom, i posebno s pravom i standardima današnje Europske zajednice. Riječ je prije svega o ustavnom prihvaćanju vrijednosti i institucija američke i europske demokracije, izražene u načelima o poštivanju prava čovjeka, o diobi vlasti, o vladavini prava i demokratskom višestranačkom sustavu. ${ }^{81}$

Ustav Republike Hrvatske prihvatio je dakle ab initio: „,vrijednosti i institucije američke i europske demokracije, izražene u poštivanju prava čovjeka, o

\footnotetext{
79 Kohylova Katarina, op. cit., p. 13 et passim.

80 F. Tuđman, Govor u prigodi proglašenja Ustava Republike Hrvatske, Zagreb, 22. prosinca 1990., http:// www.tudjman. hr/govori/proglasenje-ustava-republike-hrvatske/.

81 Tuđman, F., Govor u prigodi proglašenja Ustava Republike Hrvatske, Zagreb, 22. prosinca 1990., http:// www. tudjman.hr/govori/proglasenje-ustava-republike-hrvatske/.
} 
diobi vlasti, o vladavini prava i demokratskom višestranačkom sustavu“. Ako je Ustavni sud Republike Hrvatske od početka svog djelovanja u novoj Republici Hrvatskoj svoj smisao i raison d'etre tražio u „stvaranju čvrstih pretpostavki pravnog poretka zasnovanoga na cjelovitoj, djelotvornoj, demokratskoj, državnoj i društvenoj preobrazbi“ i podupirao "društvo pravde i blagostanja“ - a vjerujemo da jest - onda bi Ustavni sud RH i u mogućnosti svoje potrage za perspektivnim ispitivanjem sukladnosti sadržaja pitanja referendumske inicijative iz 2018. s Ustavom trebao odlučno nastaviti putem daljnje konsolidacije i učvršćenja vladavine prava u Republici Hrvatskoj. Zato bi upravo ustavne vrednote i njihovo proaktiono ustaunodemokratsko značenje i tumačenje trebali biti ultimativna inspiracija sucima $\mathrm{u}$ obrani digniteta i autoriteta hrvatskog Ustava koji svojim slovom $i$ duhom nije, niti je bio, niti bi trebao biti, produkt populističkih fantazija, napuhanih deformacija i diverzija pseudodemokratskih inicijativa te svega onoga što objektivno blokira njegovo dosljedno ostvarivanje. 


\section{Summary}

\section{Institutions of Direct Democracy in the Network of Political, Legal and Populistic Constitutionalism}

This text is about the place, role and relation of the representative system and direct democracy within the triad of political, legal and populistic constitutionalism. Also, it is directed at constitutional-theoretical and political apology of constitution and constitutionalism. This is in particular at the role of constitutional judiciary within the context of the reasons and limits of using institutions of direct democracy within the constitutional democratic organisation of contemporary government powers. It, in particular, sets out the reasons for which, according to the author, constitutional democratic understanding of the text of the Constitution of the Republic of Croatia does not register low frequencies of warning calls of recent referendum initiatives. Concretely, they are those which aim at change to art. 72 of the Constitution - number of representatives in Croatian parliament and amendments to Constitution art. $72 \mathrm{a}$ - on taking away the voting rights for national minority representatives to vote on confidence to the government and budget. It is the author's conclusion that it is about attempts to constitutionalise reductionistic anti-egalitarian ideas of actual populistic Sturm und Drang. In this and similar contexts, the Constitutional Court acquires the imperative task of defending constitutional values from excessive activism and from both various demagogically-conservative groups and bureaucratic and indifferent party formations of Croatian representative democracy.

Keywords: representative system; direct democracy; referendum; populism; Constitutional Court. 